\title{
Spatial Modeling of Transformation of Public Open Spaces in Zarqa, Jordan
}

\author{
Monther Dahash Jamhawi ${ }^{1 *}$, Rami Khaled Al-Shawabkeh ${ }^{2}$, Esraa Issa Alobaidat ${ }^{1}$ \\ ${ }^{1}$ Department of City Planning and Design, Faculty of Architecture and Design, Jordan University of Science and Technology, \\ Irbid 22110, Jordan \\ ${ }^{2}$ Department of Architecture, Faculty of Engineering, Al al-Bayt University, Mafraq 25113, Jordan
}

Corresponding Author Email: mjamhawi@gmail.com

https://doi.org/10.18280/ijsdp.150511

Received: 5 March 2020

Accepted: 19 May 2020

\section{Keywords:}

successful open spaces, informal spaces, adequacy, Zarqa City, Geographic Information Systems (GIS)

\begin{abstract}
In the recent urban development of the city of Zarqa in Jordan, the public open spaces in this city have not been designed to accommodate the high and rapid population increase. As such, Zarqa city does not have adequate public open spaces that meet the users' needs. As a result of inadequate public open spaces, people created new informal open spaces to practice recreational, and other, activities. This research investigated success of formal (officiallyorganized) public open spaces and the informal spaces created by users according to the indicators of successful public open spaces. It used qualitative and quantitative approaches using Geographic Information Systems (GIS) and a questionnaire survey. The primary data were collected using various tools like the questionnaire and the GIS whilst the secondary data were obtained from the literature. This study concludes with a spatial model consists of multirecommendation contributing the success of public open spaces in Zarqa City. This model gives an opportunity to guide the government, municipal authorities, planners, and decisionmakers responsible for designing public open spaces to enhance the future community-friendly spaces in cities suffering unplanned urban and population growth. The significance of this study is that it is the first specifically examining the designing public open spaces in Jordan. This model therefore can be applied to other Jordan cities that are similar to Zarqa City. It can also be developed further in order to inform the similar works that are being undertaken in developing countries cities in terms of urban development and population growth.
\end{abstract}

\section{INTRODUCTION}

This research is about the successful public open spaces using the case of Zarqa city. In the last few decades, the world has witnessed tremendous development and population growth, especially in developing countries, that has not been evenly distributed [1-3].

Rapid development led to decline in the quality of public open spaces, especially in the contemporary design of these spaces [4], and even their negligence in parts of the world [5]. The lack of public open spaces pushes people to create their own spaces for social meeting [6]. Consequently, the people travel outside the city for recreational activities or utilize the accessible informal open spaces $[7,8]$.

According to the literature on history of growth and development in Zarqa City, there was no interest in the development of public open space in this city [7]. In the time being, there is a pressing need for studying the spaces that have been newly created, especially the 'informal' open spaces in this city, which were created by people and were not examined by researchers so far [8].

The main aim of this research was to examine the characteristics of successful public open spaces in Zarqa City and propose a framework for designing successful public open spaces by making better use of the successful informal spaces and/or transforming the informal spaces into officiallyorganized spaces. Therefore, the main research questions are:
(1) Are the public open spaces in Zarqa City adequate? (2) What are the weaknesses of the official public open spaces in Zarqa City? (3) What are the distinguished features of the informal public open spaces that can be taken into account for enhancing the creation of formal public open spaces? (4) Is it possible to transform the informal public open spaces into officially-organized open spaces?

In the next part of this paper, the literature on successful public open spaces is explained. The second part discusses the methodology applied. The last part presents results, discussions, conclusions, practical implications and contribution to the knowledge.

\section{LITERATURE REVIEW}

\subsection{Public open spaces}

Mattson [9] assumes that public open spaces are used to meet people's needs, where they interact with each other in cities to enhance their social life and exchange their different views on everyday issues. Historically, public open spaces played an important role in the cities and their social structures [10]. Over the years, the public open spaces have gained considerable importance for the roles they played like markets, playgrounds, and social meeting places [11].

There are various types of public open spaces. Lynch [12] 
has classified these spaces as regional parks, squares, plazas, linear parks, adventure playgrounds, wastelands, playgrounds, and playing fields. In terms of their functions, these spaces have been categorized as relaxation and recreation spaces, wildlife preservation areas, natural and agricultural resource lands [13].

According to Carmona, public open spaces are classified into 20 types in four categories; positive, negative, ambiguous, and private spaces. Firstly, positive space is defined by tangible things such as fences, buildings, trees, columns, walls, and level spaces without continuous boundary. Secondly, private spaces are defined as external spaces that are private and not open to the public. Thirdly, negative spaces are defined as spaces that do not have a specific shape and which are difficult to imagine [14]. These spaces are called antisocial behavior spaces, where racism, tampering, and vandalism activities are common and often make these spaces threatening places [15]. The last type of public open spaces is ambiguous spaces like the 'third places'. This notion of 'third places' was originally formulated by Oldenburg [16]. These places are informal spaces outside homes such as grocery stores, traditional streets, and roads. They have become essential for the individual and society. Oldenburg [16] stated that the third places are informal public spaces. Carmona confirmed the presence of informal spaces in London where these spaces have many shapes and uses as parking roadway, street, and informal space for pedestrians.

The concept of public space is itself a slippery concept [17]. Carmona [18] stressed that such spaces should be accessible to various groups of people from city streets or squares to the own home environment. It is worth to mentioning that there are many public open spaces in developing countries that include infrastructure facilities (pathways, water supply lines, electricity facilities, drainage pipes or channels, lighting), and centers of religious and cultural nature, in addition to sites for recreational and social activities. In the developing countries, authorities do not give more attention to the public open spaces because these countries mostly use short-term and lowcost plans. The authorities in most of these countries are mainly concerned with providing the infrastructure. Despite ongoing development of public open spaces in developed countries, these spaces are often neglected in developing countries and transformed into unsuccessful spaces [19].

Zarqa city goes through a situation similar to what is common to other developing cities and suffers from the uncontrolled growth and diversity of the population. Public open spaces in this city have not been prepared to accommodate the population increase and contribute to an improvement in the residents' quality of life. As a result of degradation and overcrowding, the available public open spaces did not meet the resident's needs of recreational areas [20]. In Zarqa city, people tend to organize their space without the assistance of any professional body as a result of the shortage of public open spaces.

\subsection{Informal spaces}

The daily life of people mainly revolves around three important contexts: homes, where family and private activities are practiced; the workplace, where income is generated for improvement of the economic condition; and other places that are not home or work. These are collectively referred to the third places, which form informal spaces [21, 22]. These spases are defined as spaces that are not officially recognized as parks or other public open spaces and not officially considered as such by the authorities, wherein dwellers can practice sports, play games, relax, and perform other forms of recreational activities. They may exist in privately-owned yards, empty lots, alleys, or some other forms of open spaces [21].

The third places refer to informal gathering places that are good places for social activities and interaction between people outside the workplace and home. As Oldenburg [16] states that they are nothing more than places for informal public gatherings like cafes and entertainment centers. These spaces have an important role in enhancing the quality of life [22], which leads to good economic returns in various facets [23]. In fact, the third places are used in modern economic production [24].

The third places are characterized by several characteristics. In specific, they are neutral territory that is easy and free to access. They are places where people meet at different levels of social activities like playing and drinking [24].

Informal spaces were created in London through preference and reclamation. For example, parking spaces or roads and sidewalks are used; they were reclaimed and used as informal spaces [25]. In this context, Aljafari [8] stated that Queen Alia Airport Road in Amman is an important route. It is being used as informal and quiet spaces away from the crowded areas. Various activities are carried out by users along this road such as interaction, recreation activities, and barbecuing.

The spatial needs and shares of the population are very important reasons for creation of informal spaces, which were created to enable recreational and non-recreational activities. This makes people feel free and they do not need to set criteria of membership [8]. The formal spaces, however, suffer from poor conditions, high deterioration, poor maintenance, and crowds, besides being fenced and requiring entrance fees [21, 26, 27].

Emergence of informal open spaces in cities has been strongly related to the spatial needs of the population. According to the World Health Organization (WHO), an area of $9 \mathrm{~m}^{2}$ of green space per inhabitant of the city is needed. This figure corresponds to about 0.9 ha per 1,000 inhabitants. The National Recreation and Park Association (NRPA) in North America has recommended an area of 10 acres (4.1 ha) per 1,000 residents while the National Playing Fields Association (NPFA) of Britain recommends the area of 6 acres (2.4 ha) per 1,000 residents. In fact, there are noticeable differences in the per capita share of public open spaces from one country to another, even though this measure has become controversial [28].

According to the Cities and Villages Organization Law No. (79) in 1966 and the Buildings and Organization Law No. 67 in 1979, there is a lack of implementation and compatibility of these laws with population growth. In addition, there is a lack of neighborhood formation and the provision of the necessary public services. Public services were discussed in general, without looking at the challenges of their uses, proportions, area, places, and the minimum per capita of them [29]. The per capita share of public open spaces in Zarqa City has dropped. Unfortunately, the high population growth in the city has led to an increase in buildings and overlooking of the provision of public and green spaces for the society. In addition, the available public open spaces suffer from traffic congestion and crowds [20].

It is attributed to many reasons, including urbanization at the expense of recreational and green spaces and the need for 
membership or fees for entry to some spaces. Given the stagnant economic condition of Jordan, the public open spaces are costly and not affordable to all. This is aggravated by the lack of varied opportunities or types of public open spaces to serve the population since almost all the existing spaces are similar and their goal is financial consumption [8].

\subsection{Importance of the public open spaces}

Public open spaces have great importance and social, environmental, and economic benefits. These spaces are very important in enhancing life from several facets like health, social interaction, and economic value [30]. Public open spaces are places where people interact and feel privacy [27, $31,32]$. In recent times, these spaces have grown into an essential element in physical planning and development [31], bearing in mind that they serve many functions, including recreation, protection of the visual character, conservation of heritage, sustaining beauty of a city, and meeting the residents' social, political, economic, and aesthetic needs [27]

Public open spaces are the key facilities that are intended to encourage various physical activities [30,33], social cohesion and health [27, 30, 33-35], and also to improve social interaction and economic value of life in cities [30,33]. These spaces have valuable environmental functions in filtering the wind and water in the city [31] enhancing the quality of life. This therefore provides areas that contribute to aesthetics, health, education, and economy [27, 31]. In consequence, presence of these places in cities and neighborhood setting is not only important at the human level, but ultimately for the city development [27, 34].

Sherer (2006) maintains that the public open space has many benefits as it enhances health of the city community and makes cities livable and attractive. in general, the benefits of the open spaces in the urban setting in spite of the different terminologies they use to refer to them were agreed [36].

\subsection{Responsive public open spaces}

Carr, et al. [37] illustrated that the public open spaces are meaningful and responsive places that are available to all people. Krueger et al. [38] stated that the democratic space, which provides diverse activities for all people, is a responsive place. Carmona et al. [39] clarified that the responsive spaces give people the opportunity to determine the direction; where to go and where not to, and to understand the possibilities and opportunities offered by the space. Carmona et al., [39] further explained that the responsive spaces are flexible, diversified, clear, and personalized spaces, which are characteristics that increase the use of these spaces.

Charkhchian and Daneshpour [40] illustrated that the responsive spaces have different dimensions [41]. The first dimension is physical dimension, in which a large number of researchers were interested $[37,41,42]$. The second dimension is the activity, where many researchers have conducted studies on the effect of activities in the responsive spaces [37, 43]. Also the social dimension forms the third dimension [37, 44], while meaning is the fourth dimension [45]. Charkhchian and Daneshpour [40] maintains that the physical response of the place is summed up by several important factors like security and safety, comfort in all its forms, access to these spaces, and the availability of important elements such as natural elements. In the sequent sub-section, these four features are discussed.

Besides physical responsiveness, social activity responsiveness is very important [40]. Social activity responsiveness implies that the activities depend on the social characteristics of these spaces [46]. Examples of these activities include entertainment, playing [37], and other intangible activities like meditation, relaxation, and creation of peace of mind in the public open spaces [40]. Provision of good physical features and amenities in the public spaces can help in organization and implementation of successful social activities and establishment of comfortable public open spaces [46, 47]. Active and passive recreation can attract users to these spaces [43]. Passive recreation encircles meditation, relaxation, and other activities [37]. In fact, these characteristics provide varying opportunities for entertainment and help attract and satisfy the users [48].

In fact, social activities constitute an important factor in the success of public open spaces, which help in satisfying people [46] and enabling them to meet and interact with each other [40], therefore giving an impression of quick response to this place [46]. The social responsiveness of the public open space is realized by many factors and elements, including places for sitting, gathering, and communication; festivals; celebrations; and performance of various arts [48]. In addition, other physical amenities are very important in good social responsiveness, for example, eating places and markets [49].

The final dimension of the responsive public open spaces is meaning. This aspect of the responsiveness is very important depending on the physical [50], social, and activity responsiveness [51]. The meaning responsiveness is influenced by many factors, such as; cost, signs, heritage, and duration. When people stay in these spaces for a long time, this will give meanings to these spaces [52]. Moreover, different characteristics contribute to success of the meaning of responsiveness, including cultural, social, and individual characteristics of the place [53]. In consequence, if the designers consider these characteristics by engaging the community, therefore this will develop the meaning of the space [54].

\subsection{Success of public open spaces}

The good public open spaces are characterized by fair access of all groups of the society of different ages, social levels, and physical abilities. Additionally, they are characterized by the accessibility of disabled people $[37,55]$. Success of these spaces depends on accessibility which can be assessed by distance to these spaces, whether it is short or long $[40,56]$

Though, Németh et al. [57] asserted that the access is not a prominent and important factor in these spaces and their success. Rather, it is the margin of freedom and level of security in these spaces. According to Billingham's [58] definition, the successful public open spaces have many characteristics such as being available all the time, useable for different purposes, attractive, and visually appealing.

Many researchers evaluated success of these space based on measures of safety, allowance for a variety of uses, appropriate environmental conditions, and being pollution free, distinctive, and available for free [58]. Nasar stated that the public open space should have other characteristics such as presence of natural elements, roominess, order; maintenance; and having historic importance.

Successful public open spaces have natural elements near paths and sitting places that can improve the inappropriate climate, if any, and offer comfort and relaxation in the places where people perform many activities like sitting, dining, 
selling goods, performing physical activities, and searching for comfortable experiences [37, 46]. Other studies support that the successful public open spaces are the places that can be used by diverse people on various occasions [59].

Physically, the public open space should be easy to use, clear, and having clear and connected traffic paths $[37,46,60$, 61]. To the contrary, Askari and Soltani, [32] underlined that the physical features of the public open spaces, such as access to all that enable interaction with different people despite differences between them have the least influence on success of these spaces. Nasution and Zahrah [30] pointed out that the public open spaces consist of six success factors: accessibility, facility, activity, management, natural environment, and intensity.

Askari and Soltani [32] stated that the freedom and personal safety of the users, rather than accessibility, are the success factors of public open spaces. Other studies found that distance was the major factor in success of public open spaces. It is measured using the time it takes to reach these places, approachability, the ability to enter these places, street type, availability of public transportation [5, 30, 62], the sizes of the places [5, 62], and the use intensity which can be measured by the population density [62]. The congestion level, placing of sitting area, maintenance and safety are measures of comfort $[5,63]$. Also the quality can be measured by the available facilities and the diversity of activities that can be performed in these spaces. Lastly, the aesthetic considerations can be measured by security, upkeep, and elements of attractiveness [30, 63-65].

Thus far, there are many models of public open spaces such as project for public space (PPS), Lennard [66], Jan [67], and Carr et al. [37], have identified other indicators of a successful public space [40] as shown in Figure 1.

Lennard and Lennard [66] affirmed that the indicators of success of the public open space are curiosity and exploration, variety of activities, good definition and orientation, place image and character, and memories and sense of place. Project for Public Space (PPS) has found that the successful public open spaces share four qualities: accessibility, comfort, good image, and sociability. Carr et al. [37] argue that the indicators of success of the public open space are being meaningful, democratic, and responsive. Gehl [67] stated that the indicators of success of the public open space should be comfort, enjoyment, and protection. The literature review shows that some characteristics of the public open spaces in previous models refer to primary and superior human needs [40].

According to the model of Charkhchian et al. [40], the researchers developed a new model based on previous models, human needs, and an experimental study in which they researched into success of public open spaces in terms of four dimensions: physical, activity, social, and meaning dimensions (Figure 2).

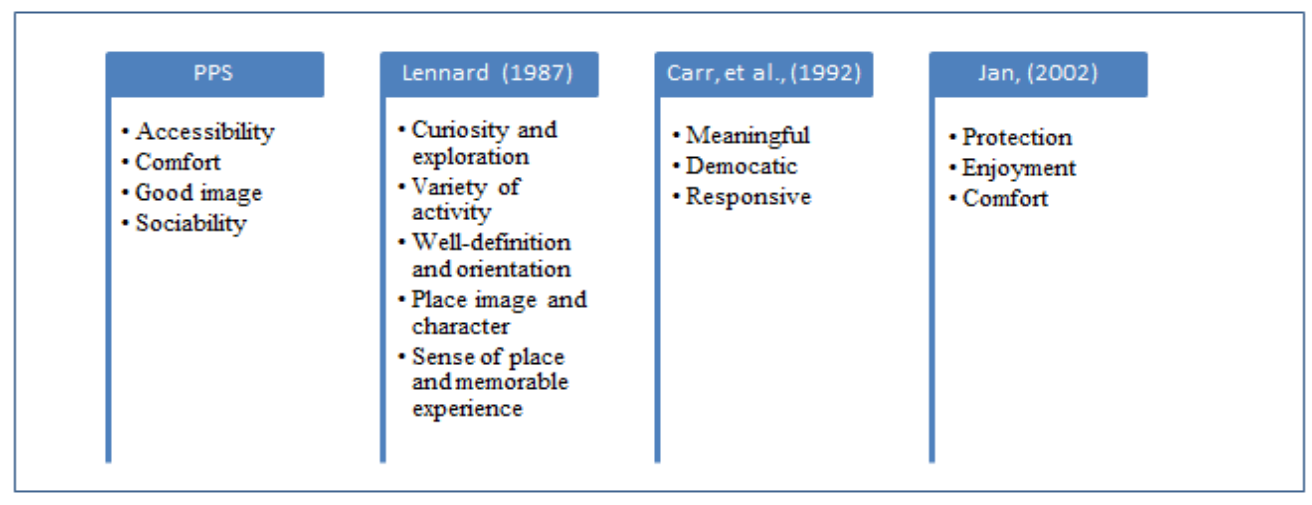

Figure 1. Success factors for public open spaces from the perspectives of different researchers (Source: Charkhchian and Daneshpour [40])

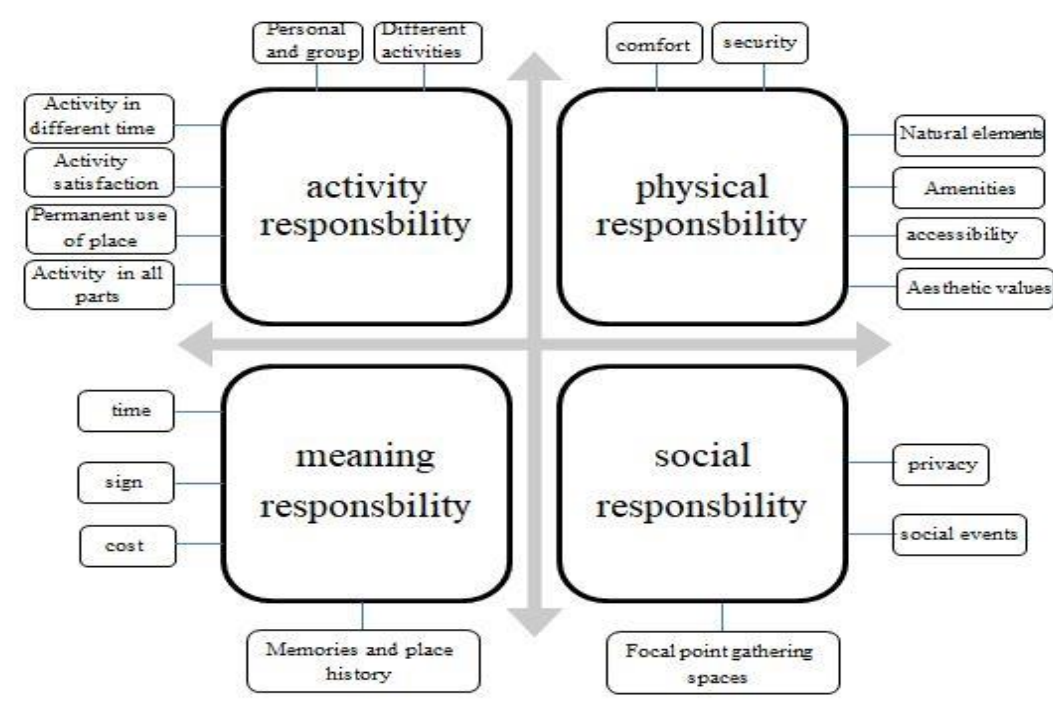

Figure 2. Suitable model for public open spaces (Source: Charkhchian and Daneshpour [40]) 
Literature review discussed aspects related to public open spaces, including the definition of these spaces, their types and importance. Moreover, this section examined the success factors of public open spaces and shed light on their indicators. Furthermore, it reviewed models relating to the successful public open spaces like the project for public spaces (PPS) and the models of Lennard [66], Carr et al. [37], Gehl [67] and Charkhchian and Daneshpour [40]. Further, this section touched upon the informal space. By so doing, this chapter outlined the theoretical framework of this study, which helped the researcher in developing a conception for successful future public open spaces in Zarqa City. Indeed, there are no studies of the public open spaces in Zarqa City in terms of their types, management, and design, as well as of how they are produced, what people preferences of these spaces are, and, most importantly, how the society of Zarqa creates new spaces and utilizes them. In this study, an analysis of the public open spaces, both formal and informal in Zarqa city was performed to identify these spaces and assess their degree of success. Based on the analysis outcomes, the study proposes a spatial model that is due to guide the involved official bodies (e.g., the municipal authorities) in the planning and design of these spaces in cooperation with the community. This will contribute to creation of public open spaces and making more space available for recreational public use to improve the quality of life of the local people.

\section{THE STUDY AREA}

The Hashemite Kingdom of Jordan is an Arab country in Western Asia, on the East Bank of the Jordan River [68, 69].
Jordan is bordered by Syria to the north, Iraq to the northeast, Saudi Arabia to the east and south, and Palestine to the west [70, 71]. Zarqa is the second largest city in the Hashemite Kingdom of Jordan after the capital, Amman, in terms of the general economic activity, and the third largest city in terms of population. The city lies $20 \mathrm{~km}$ to the northeast of Amman [72]. It is located between the latitudes of $32^{\circ}$ and $33^{\circ}$ [6]. Zarqa governorate consists of seven municipalities: Zarqa, Russeifa, Al Hashimiyah, Ad Thulail, Al Hallabat, Al Azraq, and Berrien (See Figure 3). It has a land area of $4,761.3 \mathrm{~km}^{2}$ with a population of $1,439,500$ capita [73].

According to the department of statistics (2018), Zarqa city had a population of 866,400 capita in 2018 , which constituted $51.8 \%$ of the population of the governorate of Zarqa $(1,474,000)$. This population comprises $51.7 \%$ males and $48.3 \%$ females. The average household size is 5.4 persons, which is comparable with the national average of 5.2. persons [73].

The history of Zarqa city goes back to around 3000 BC [74]. The city passed through many periods such as the Roman era [72], the Umayyad Islamic period in the $7^{\text {th }}$ century, and the Ottoman Islamic period in the $16^{\text {th }}$ century (Figure 4). Importance of Zarqa city increased during the Ottoman Islamic period when Al-Hijaz railway line was extended during the period 1900 to 1908 to link Mecca with Istanbul. The railway passed through Zarqa for the purpose of pilgrimage. In 1902, the Chechen people coming from central Asia started to settle in Zarqa City around Zarqa stream [75, 76]. In 1926, Zarqa became the base for the military force. This necessitated construction of a large number of houses for the workers in the military force and their families without planning [20].
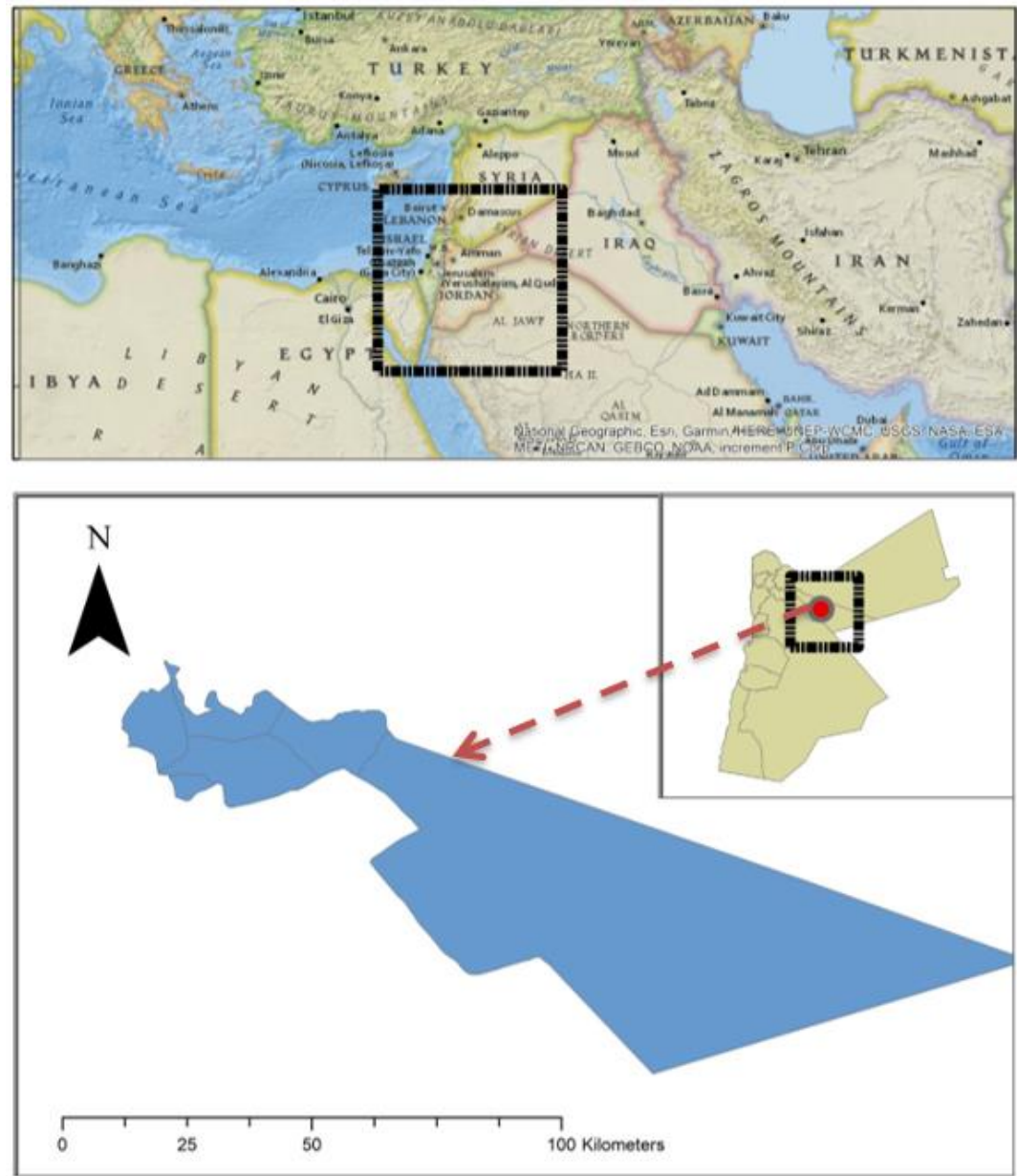


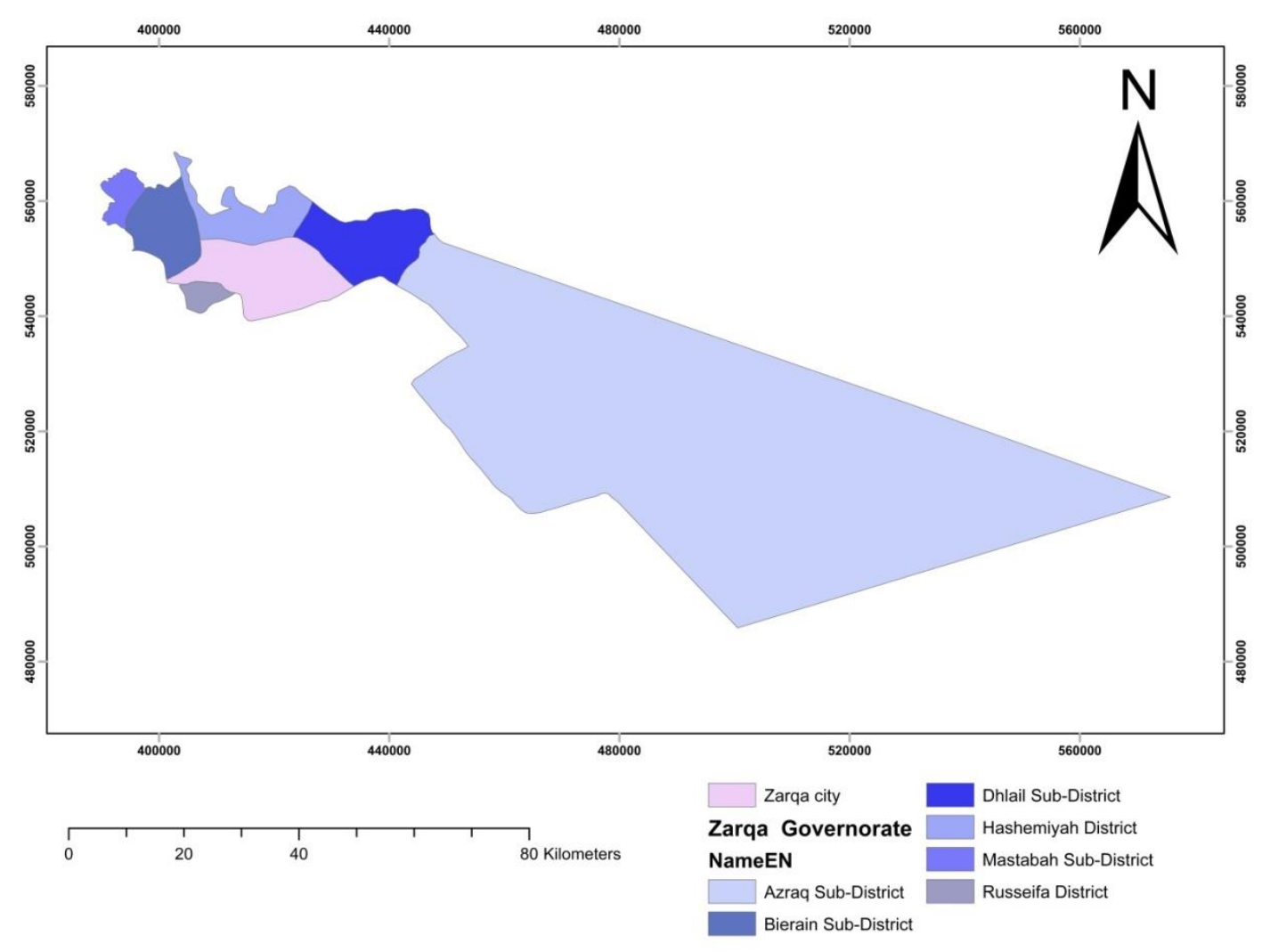

Figure 3. Zarqa city in the Hashemite Kingdom of Jordan (Source: The author 2018 using GIS10.3)
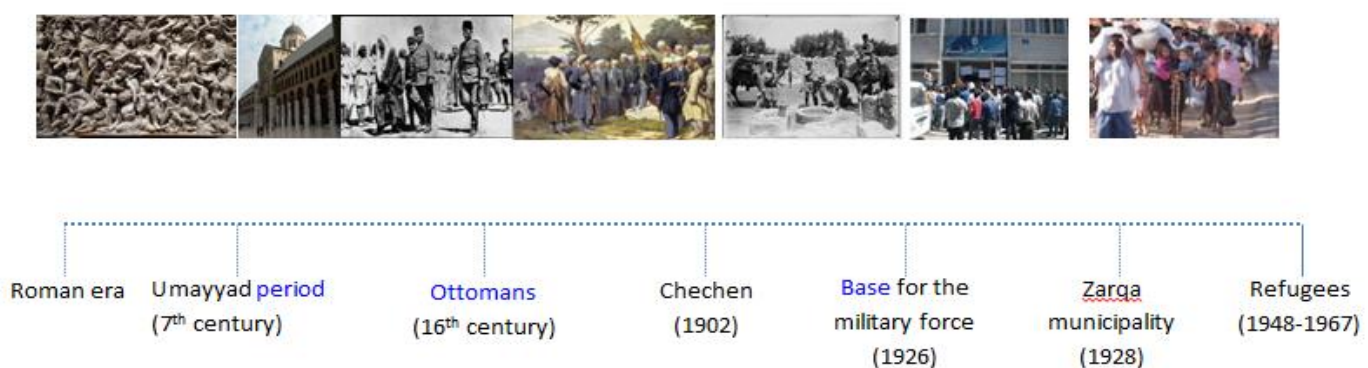

Figure 4. Prominent points in the history of Zarqa City (Roman era-1967) (Sources: Abu-Gazalah, 2004). drawn up by the author

Several reasons stand behind selecting this particular governorate as the study area. The first reason is that the city of Zarqa is the second largest city in Jordan after the capital, Amman, in terms of the general economic activity, and the third largest city in terms of population density [72, 75]. Secondly, it has witnessed high population density and high urban growth that led to a reduction in the proportion of open spaces and the emergence of new informal open spaces [6] Lastly, there was the rapid expansion of Zarqa City with decline in the quality of the public open spaces in the city [5]. According to the literature on growth and development of Zarqa City (See Figure 4), there has been an absence of interest in the development of its public open space [20].

To avoid confusion in the definition of public open spaces in this research, the definition of the public open spaces used in this study was based on a compilation of the definitions of the Greater Amman Municipality [77], Greater Zarqa Municipality[6] and the classification of public open spaces of Carmona [14] (See Figure 5).

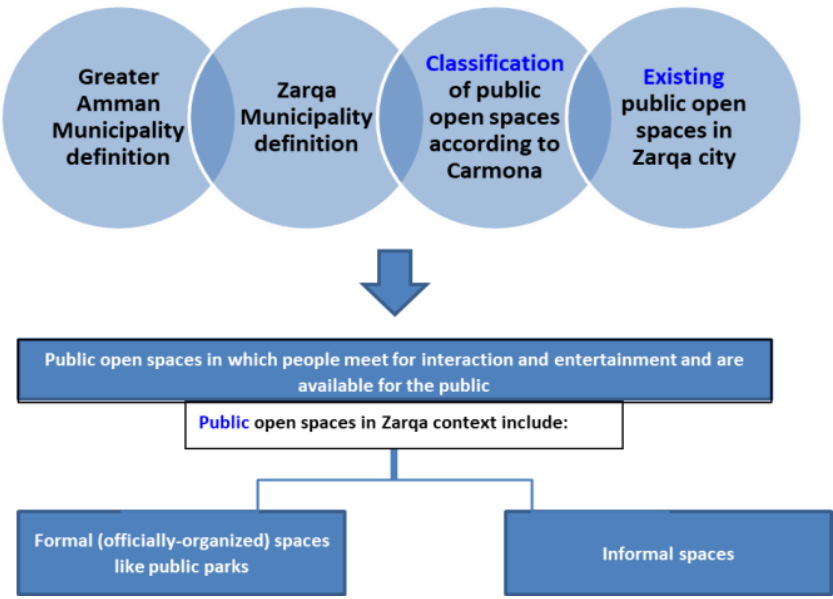

Figure 5. Reference definitions of public open spaces for this study. Drawn up by the author 


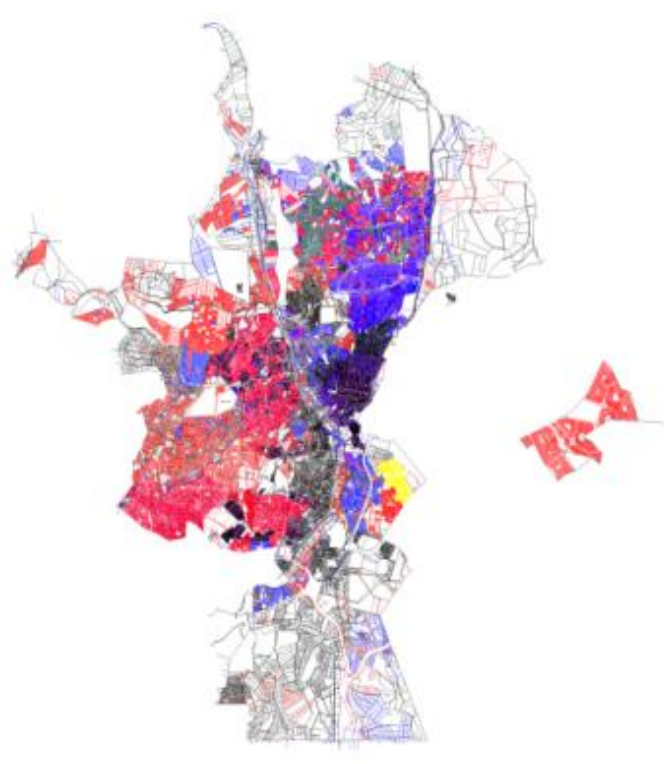

Figure 6. Zarqa City (Source: Zarqa Municipality, 2017). Modified by the author 2018

Table 1. Parks name (Source: The author)

\begin{tabular}{|c|c|c|c|}
\hline Park name & $\begin{array}{c}\text { Neighborhood } \\
\text { name }\end{array}$ & Park name & $\begin{array}{c}\text { Neighborhood } \\
\text { name }\end{array}$ \\
\hline $\begin{array}{l}\text { Al-Fayhaa } \\
\text { Park }\end{array}$ & Al-Zawahreh & $\begin{array}{l}\text { Albatrawi } \\
\text { Park }\end{array}$ & Al-Hashemeya \\
\hline $\begin{array}{l}\text { Queen Noor } \\
\text { Al Hussein } \\
\text { Park }\end{array}$ & Al-Zawahreh & $\begin{array}{c}\text { Royal } \\
\text { Village Park }\end{array}$ & Ramzi \\
\hline $\begin{array}{c}\text { The } \\
\text { Hashemite } \\
\text { Hall }\end{array}$ & Al-Qwaireyeh & $\begin{array}{l}\text { Al-Quds } \\
\text { Park }\end{array}$ & Ramzi \\
\hline $\begin{array}{l}\text { Al-Tefel } \\
\text { Park }\end{array}$ & Al-Qwaireyeh & $\begin{array}{c}\text { Al- } \\
\text { Muhandes }\end{array}$ & Ramzi \\
\hline $\begin{array}{l}\text { Mausoom } \\
\text { Park }\end{array}$ & Mausoom & $\begin{array}{c}\text { Military } \\
\text { College Park }\end{array}$ & $\begin{array}{c}\text { Al-Thawrah } \\
\text { Al A'rabeyah } \\
\text { Al-Kubra }\end{array}$ \\
\hline $\begin{array}{c}\text { Municipality } \\
\text { Park }\end{array}$ & Al-Hadeqa & $\begin{array}{l}\text { Armed } \\
\text { Forces } \\
\text { Officers } \\
\text { Club }\end{array}$ & $\begin{array}{c}\text { Al-Jabal Al- } \\
\text { Abyad Quarter }\end{array}$ \\
\hline $\begin{array}{l}\text { Al-Jundi } \\
\text { Park }\end{array}$ & Janaa & $\begin{array}{c}\text { Governorate } \\
\text { Park }\end{array}$ & Janaa \\
\hline $\begin{array}{c}\text { Jabal Al- } \\
\text { Almira } \\
\text { Rahma Park }\end{array}$ & $\begin{array}{l}\text { Princess } \\
\text { Rahmeh }\end{array}$ & $\begin{array}{l}\text { Al-Eskan } \\
\text { Park }\end{array}$ & Al-Eskan \\
\hline
\end{tabular}

Through tuning literature on the public open spaces in Zarqa city and related data obtained from the municipality of Zarqa, it was found that the public open spaces in this city consist of informal spaces, circles, and parks in different locations in the city neighborhoods [7]. The circles were excluded from this study because they are just intended for aesthetic purposes as a landscape of the city, not as public open spaces [7, 20]. Public open spaces such as parks and circles existing in Zarqa city accord with Carmona's (2010) classification of public open spaces, namely, the positive and ambiguous spaces. Formal public open spaces (officially-organized spaces) as selected by the municipality of Zarqa are depicted in Table 1. The adopted definition refers to the public open spaces as places in which people meet for interaction, and entertainment, which are available for the public. According to the definition of Greater Amman Municipality, public open spaces are physical spaces, where people can meet for social interaction.

Informal spaces, the suitable model, and success of these spaces were evaluated using a questionnaire survey in the Zarqa context (Figure 6). In the next chapter, the methodology of this research is discussed.

\section{METHODOLOGY}

Numerous researchers used both quantitative and qualitative methods in public open space exploration such as Mean and Tims and Turel et al. [78, 79]. The mixed-research methodology corresponds to integration of qualitative and quantitative research method to ensure comprehensiveness, reliability, the accuracy of results, and the soundness of conclusions extracted from these results [80]. In addition, the mixed-approach is an effective choice that helps in improving the quality of analysis of the phenomenon of interest and the relating data [81, 82]. Thereupon, this study adopted the mixedmethod approach according to the next major steps:

(1) The use of questionnaire to study the informal spaces in Zarqa city and choose a suitable model for this research (Appendix A).

(2) Employing the GIS program and associated tools to analyze the data, mapping public open spaces, informal spaces locations, and examining the adequacy of the public open spaces in Zarqa city.

(3) The use of second questionnaire to test the chosen model indicators (Appendix B).

In this study, there were two questionnaires. The first questionnaire aimed to help the Authors for choosing the suitable model and selecting sites for informal spaces. This questionnaire consists of two sections and consisted of four open-ended questions. The first section explored demographic characteristics (age and gender) of the respondents. The second section asked the respondents to rate the use of public open spaces, their choice of public open spaces, the reasons for choosing the particular public open space. The third one was about the characteristics of a good public open space. Lastly, it asked them to give recommendations to improve the public open space.

The GIS has been defined as "automated systems for the capture, storage, retrieval, analysis, and display of spatial data" [83]. This system has recently penetrated many fields [28]. Albeit the GIS has been used in planning, it has been used far less frequently at the micro level like in public space studies. This is due to the lack of necessary data concerning public space in the local community [84]. In this study, the GIS was used to extract maps, mapping public open spaces, informal spaces locations, and measure the adequacy of public open spaces. Therefore, adequacy of public open spaces can be measured using two methods; the Euclidean buffer (simple radius methods) and network analysis [85]. The first approach is the buffer zone approach that was created using the 'Create Buffers' command. A service area of $400 \mathrm{~m}$ was specified with reference to the Foundations and Criteria for Civilizational Coordination of Open Spaces and Green Areas [86] (as shown in Table 2). This approach creates a circular range around the center point of each park. The center of each polygon of the park was created using the 'feature to point' command form the toolbox bar in the GIS. The second approach is network analysis, which was created for every point of access and the points were then joined into a single service area for each park. The street network layer was digitized manually. The street 
speed was estimated to be $20-35 \mathrm{~m} / \mathrm{min}$. The speed was incorporated with the GIS data to calculate the travel time along edges using the field calculator and the following formula:

\section{$\mathrm{T}=\mathrm{S} / \mathrm{V}$}

where, S=Length of road segment $(\mathrm{m}), \mathrm{v}=$ Travel speed $(\mathrm{m} / \mathrm{min}), \mathrm{t}=$ time $(\mathrm{min})$

A network dataset representing real-time network connections was built using the Network Analyst Extension in the ArcGIS 10.3 software.

Table 2. Specifications of the National Authority for Civilizational Coordination of Egypt regarding neighborhood open space (Source: [86])

\begin{tabular}{llc}
\hline \multicolumn{1}{c}{ Type } & \multicolumn{1}{c}{ Access } & Typical size \\
\hline Neighborhood open space & $<400 \mathrm{~min}$ & $>0.4 \mathrm{ha}$ \\
District open space & $<1 \mathrm{~km}$ or 15 min walk & $>1.2 \mathrm{ha}$ \\
\hline
\end{tabular}

The second questionnaire was used to test the chosen model indicators. The questionnaire consists of five sections. The first section explored the respondent's demographic characteristics of age, and gender. The second section asked the respondents to (i) rate the physical dimensions of the existing facilities and (ii) pinpoint the deficits of both the formal and informal public open spaces. The third section asked the respondents to rate the existing activities and their levels of satisfaction with those open spaces. The fourth section asked people to rate the privacy and other social values of the space. Then, the last section asked the respondents to rate the historical value of the space and other meaning values.

The answers to the questionnaire questions were ranked using the five-point Likert scale, which is an intelligencerelated scale $[81,85]$. It is one of the most widely-used scales. These answers were rated using a scale of five points: (1) not satisfied, (2) slightly satisfied, (3) moderately satisfied, (4) very satisfied, and (5) extremely satisfied.

In the present study, ten individuals participated in the pilot study and answered the questionnaire questions. De Vaus [87] stated that the pilot study is a helpful study to check the questionnaire and is the safest way to ensure the reliably of the questionnaire through knowing the interest of the participants in the questionnaire and the appropriate time to answer its questions. As a result of the pilot study, some complex terms were replaced with simple terms. In short, the objective of the pilot study was to increase the internal reliability of the questionnaire. Some questions in the questionnaire were excluded to make it more appealing as suggested by participants. Consequently, the questionnaire questions were rewritten to improve clarity of the questionnaire, taking into account this feedback.

The number of participants, i.e., the sample size, is determined in many ways, for example, choosing $10.0 \%$ of the whole population [88]. However, sometimes it is quite difficult to access $10.0 \%$ of the population when it is very large or its true number is not known. So, instead of $10 \%$ of the population, for a population greater than 100,000 persons the sample size of 384 persons [88] is reliable and more practical than $10.0 \%$ of the population. In both surveys, the confidence level and margin of error were $95 \%$ and $5 \%$, respectively.

The participants in this research were passers-and users at the age of 13 years and above. In the first questionnaire survey, the sample size was 200 individuals [40] with a response rate of $83 \%$. In the second questionnaire survey, the sample size was 400 participants with a response rate of $82.2 \%$. The surveys were conducted in all officially-organized and informal spaces in Zarqa City in August and September 2019. Different groups of people (residents, visitors, and workers) were included in the surveys to reduce bias and get accurate results. In other respects, to confirm validity of the results, the questionnaires should be filled up in different hours, days, and weeks [89]. In addition, different groups of people such as residents, visitors, and workers, were included to get an accurate result and reduce bias.

\section{ANALYSIS AND DISCUSSIONS}

In this part of the study, the data collected using the two questionnaires and GIS analysis are analyzed and discussed. The first section outlines and discusses the results of analysis of the data derived from the first questionnaire survey. This questionnaire was used to select informal spaces and choose a suitable model for the study area. The second section presents formal and informal public open spaces location, and information related to adequacy of the existing officiallyorganized spaces based on GIS analysis. It extracts various maps such as neighborhoods, population density, and park locations; besides network analysis and buffer zone analysis. In the third section, the second questionnaire was employed to test the public open space success indicators obtained from the selected model.

\subsection{The first questionnaire survey}

This questionnaire was intended to help to choose the suitable model and select the most appropriate sites for informal spaces. At the first stage, the results point out that there are other spaces than the officially-organized spaces which people visit like the parking lot of Zarqa governmental hospital, empty lots in King Abdullah Bin Abdulaziz Al Saud City, and Zarqa highway. According to the definition of the informal open spaces, these three spaces can be defined as informal open spaces.

In the second stage, the researcher identified the four principal factors that guide user's selection of the particular open space to visit. These reasons and the percentages of respondents given weight to each of them as shown in Figure 7. Figure 8 lists the recommendations provided by the respondents to improve the public open spaces in Zarqa.

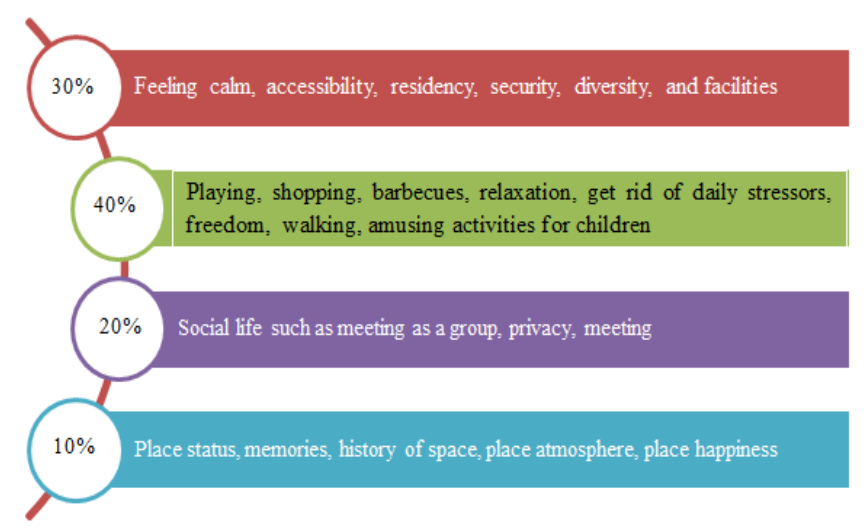

Figure 7. The reasons driving choice of the public open space to visit (Source: The author 2018) 


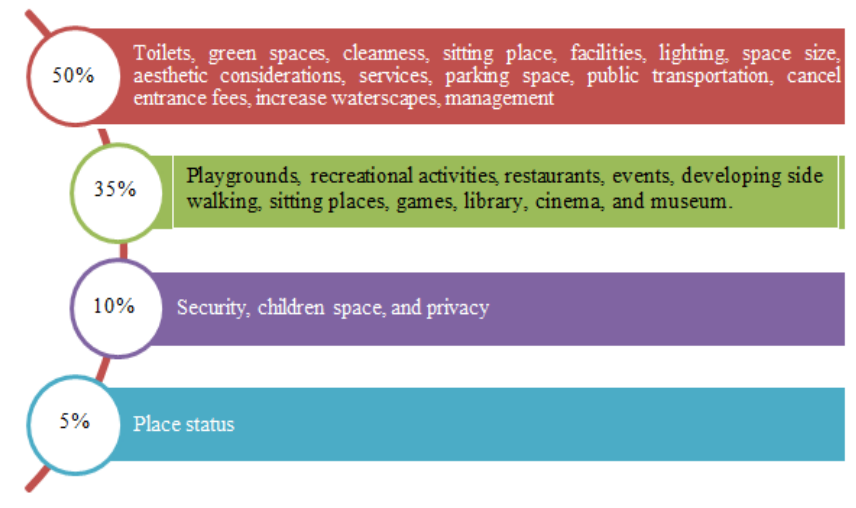

Figure 8. Respondents' recommendations for improving the public open spaces in Zarqa (Source: The author 2018)

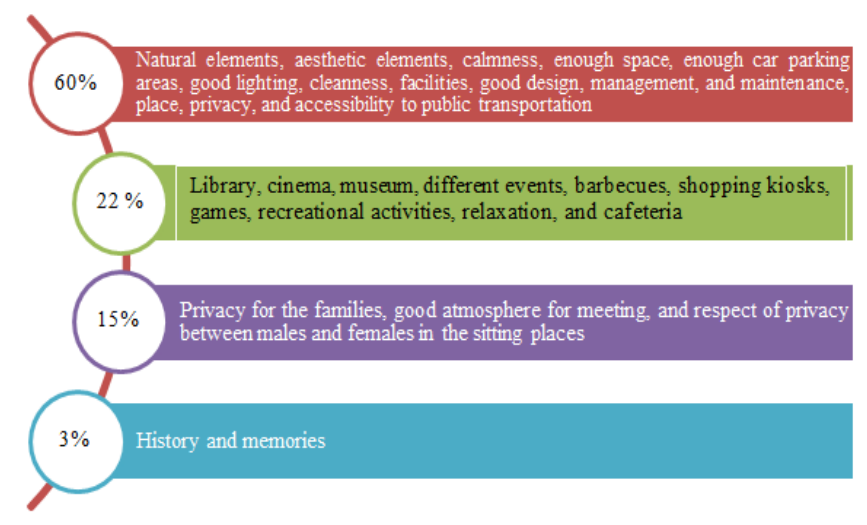

Figure 9. Respondents' views on characteristics of the good public open space (Source: The author 2018)

The participants were asked to define the characteristics of the good public open space. Their feedback suggests four groups of characteristics, namely, physical, activity, social, and meaning characteristics. As Figure 9 illustrates, the physical characteristics which have the highest weight from the respondents' standpoint while the meaning characteristics were given the lowest weight.

The results show the needs of people in public open spaces to be complying more with basic things like security, comfort, and facilities than with superior needs like aesthetic elements, social interaction, and place history. In the current study, the selected model was essentially based on the model of Charkhchian and Daneshpour [40]. Therefore, the model was used based on a match between the indicators of success of the public open spaces and participants' answers (Table 3).

\subsection{GIS analysis}

\subsection{1 locations of informal spaces in Zarqa}

The first questionnaire uncovered that the informal open spaces used the most by the users are the parking of Al-Zarqa governmental hospital, empty lots in King Abdullah Bin Abdulaziz Al Saud City, and Zarqa highway. The locations of these spaces were spotted on the map of Zarqa City using GIS as shown in Figure 10.

\subsection{2 locations of formal spaces in Zarqa}

In the first step, a map for the neighborhoods of Zarqa city was prepared. Forty nine neighborhoods within the boundary of the municipality of Zarqa have been identified (as shown in Figure 11). After mapping the neighborhoods, information on the population density of each neighborhood was added to the map as shown in Figure 12. The distribution of the population reveals that the population is concentrated in many of the neighborhoods like Ma'sum, Ramzi, Zarqa Jadidah, Gwaireyeh, Thawarah al Alrabeyah, Al-Hissien, Janaa, Commercial Center, Al-Jabal Alabyad, Prince Mohammad, King Talal, Al Naser, Prince Hamzah, Prince Hasan, Al Batrawi, and Prince Shaker. Furthermore, mapping uncovers that.

Table 3. The indicators of success of public open spaces and their measures (Source: Charkhchian and Daneshpour [40]). Modified by the researcher

\begin{tabular}{lll}
\hline Dimension & \multicolumn{1}{c}{ Indicators } & \multicolumn{1}{c}{ Measure(s) } \\
\hline Physical & Comfort and security & Security and protection from crime \\
& Accessibility & A variety of transportation options \\
& Natural elements & Green spaces and water \\
& Aesthetic values & Complexity, order, and enclosure \\
& Amenities and facilities & Service, lighting, and waste receptacles \\
Social & Privacy and territory & Is this a place which you will choose to meet your friends in? \\
& Social events & Are others meeting friends here or running into them? \\
& Focal point gathering spaces & Are people in groups? \\
& & Are they talking with one another? \\
& & Do people bring their friends and relatives to see the place or \\
Activity & point to one of its features with pride? \\
& Activity in all parts & Are people smiling? \\
& Permanent use of place & Which parts of the space are used and which are not? \\
& Activity satisfaction & Do people use the place regularly and by choice? \\
& Different activities & Are they satisfied? \\
& Activity in different time & How many different types of activities are organized? \\
& Personal and group & When are they present in the place? \\
& Cost of place & Do they use the space as singles or as groups? \\
& Time & Cost of the place \\
& Time was evaluated with users' regular presence in the place and \\
& Memories and place history & length of their familiarity with it \\
Sign & If they remember any special memory from the place \\
& & Is there any memorable sign in? \\
\hline
\end{tabular}




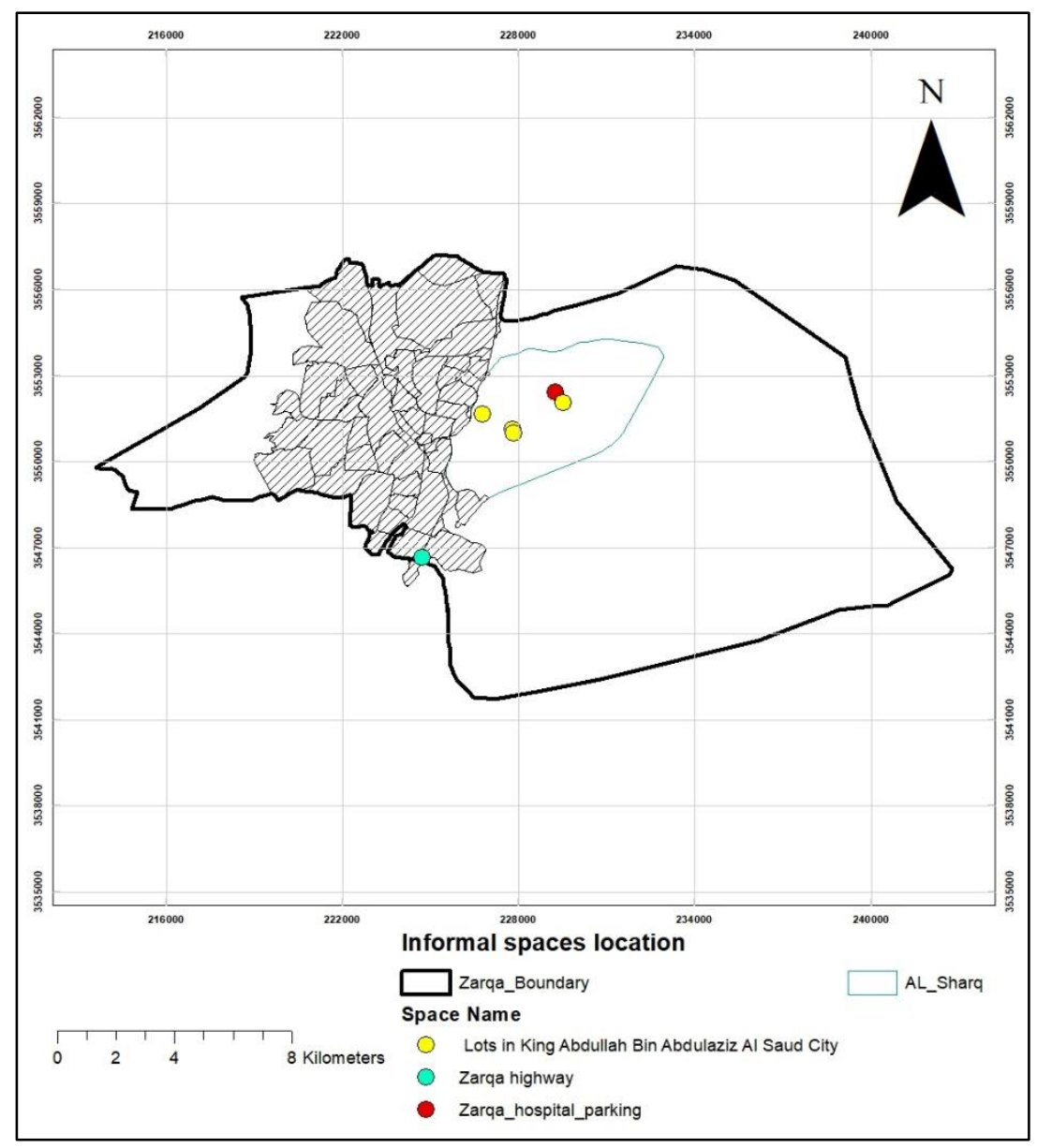

Figure 10. Locations of the informal open spaces of users' choice in Zarqa (Source: The author 2019)

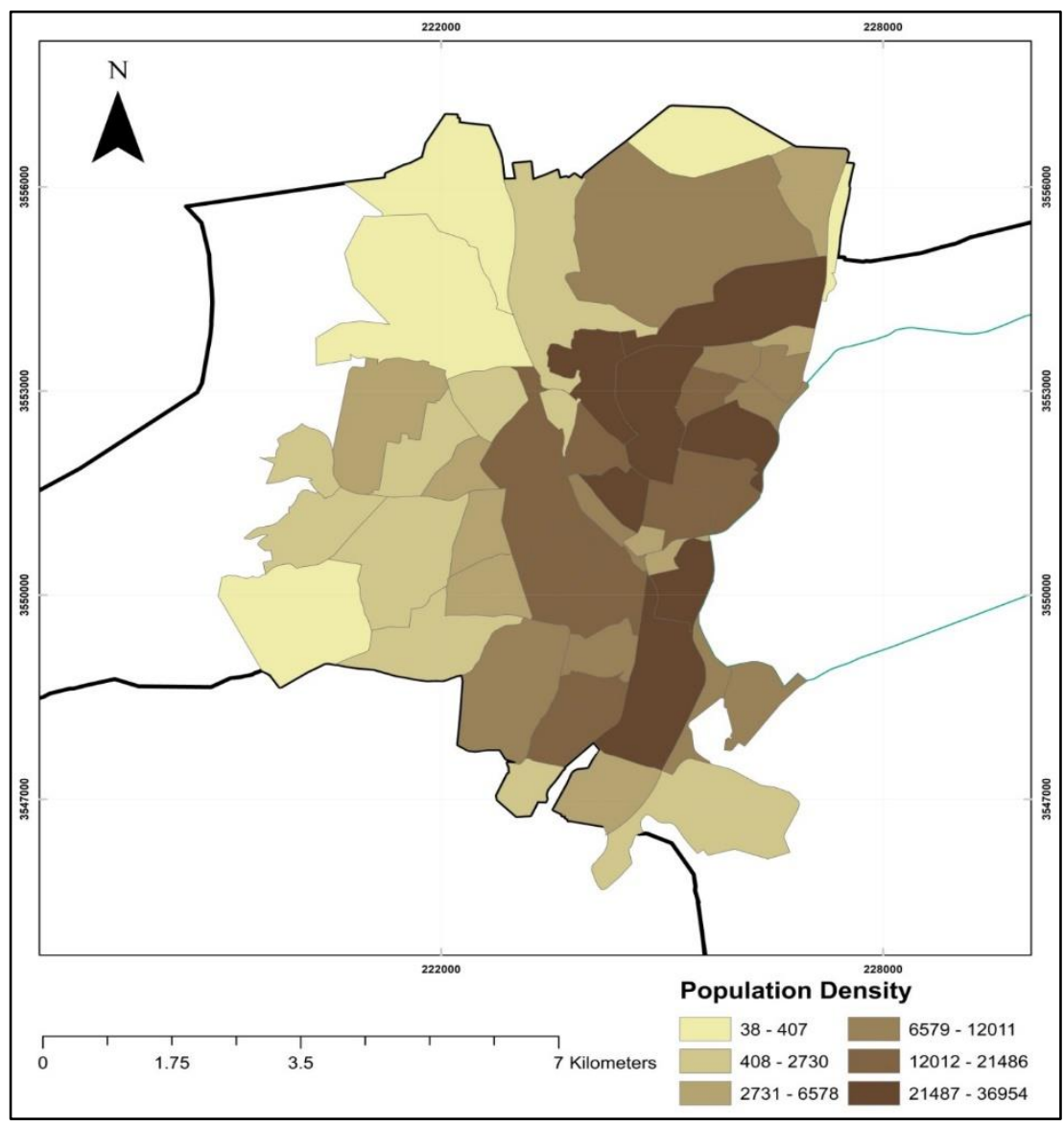

Figure 11. Neighborhoods of Zarqa City (Source: The author 2018) 


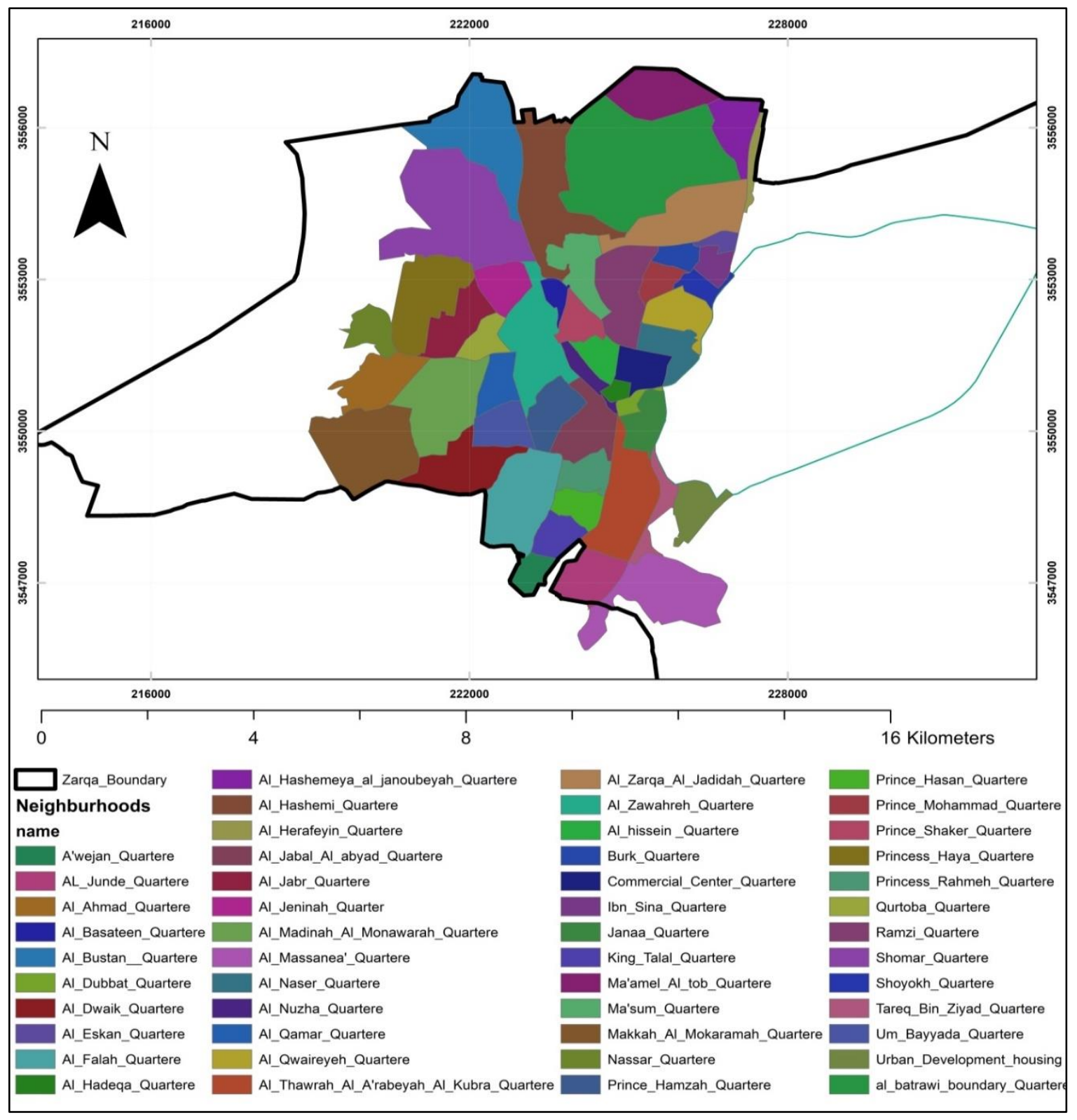

Figure 12. Population density by Neighborhoods (Source: The author 2018)

Table 4. Park areas (Source: The author)

\begin{tabular}{|c|c|c|c|c|c|}
\hline $\begin{array}{l}\text { Park } \\
\text { name }\end{array}$ & $\begin{array}{c}\text { Neighborhood } \\
\text { name }\end{array}$ & $\begin{array}{c}\text { Total area of } \\
\text { public open space }\end{array}$ & $\begin{array}{l}\text { Park } \\
\text { name } \\
\end{array}$ & $\begin{array}{c}\text { Neighborhood } \\
\text { name }\end{array}$ & $\begin{array}{c}\text { Total area of } \\
\text { public open space } \\
\end{array}$ \\
\hline Al-Fayhaa Park & Al-Zawahreh & $10,000 \mathrm{~m}^{2}$ & Albatrawi Park & Al-Hashemeya & $10,000 \mathrm{~m}^{2}$ \\
\hline Queen Noor Al Hussein Park & Al-Zawahreh & $4,000 \mathrm{~m}^{2}$ & $\begin{array}{l}\text { Royal Village } \\
\text { Park }\end{array}$ & Ramzi & $30,000 \mathrm{~m}^{2}$ \\
\hline The Hashemite Hall & Al-Qwaireyeh & $4,000 \mathrm{~m}^{2}$ & Al-Quds Park & Ramzi & $4,000 \mathrm{~m}^{2}$ \\
\hline Al-Tefel Park & Al-Qwaireyeh & $702.27 \mathrm{~m}^{2}$ & Al-Muhandes & Ramzi & $4,500 \mathrm{~m}^{2}$ \\
\hline Mausoom Park & Mausoom & $6,617 \mathrm{~m}^{2}$ & Military College & Al-Thawrah Al & \\
\hline Municipality Park & Al-Hadeqa & $8,829 \mathrm{~m}^{2}$ & $\begin{array}{c}\text { Park } \\
\text { Armed Forces } \\
\text { Officers Club }\end{array}$ & $\begin{array}{c}\text { A'rabeyah Al-Kubra } \\
\text { Al-Jabal Al-Abyad } \\
\text { Quarter }\end{array}$ & $\begin{array}{c}4,500 \mathrm{~m}^{2} \\
10,539 \mathrm{~m}^{2}\end{array}$ \\
\hline Al-Jundi Park & Janaa & $18,000 \mathrm{~m}^{2}$ & Governorate Park & Janaa & $5,280 \mathrm{~m}^{2}$ \\
\hline Jabal Al-Almira Rahma Park & Princess Rahmeh & $8,595 \mathrm{~m}^{2}$ & Al-Eskan Park & Al-Eskan & $2,500 \mathrm{~m}^{2}$ \\
\hline
\end{tabular}

Zarqa City contains 16 parks that are poorly distributed among the neighborhoods with more concentrated in some neighborhoods than the others for some parks (Figure 13, 14).

According to the digitization and consecutive calculations, the parks in the study area cover a total area of $1.320588 \mathrm{~km}^{2}$ (Table 4).
The next section analyzes the adequacy of the officiallyorganized public open spaces in Zarqa. Buffer zone analysis and network analysis were conducted using the distance of 400 $\mathrm{m}$ as the acceptable walking distances. These maps were used to evaluate the adequacy of public open spaces and the neighborhood areas which these spaces cover. 


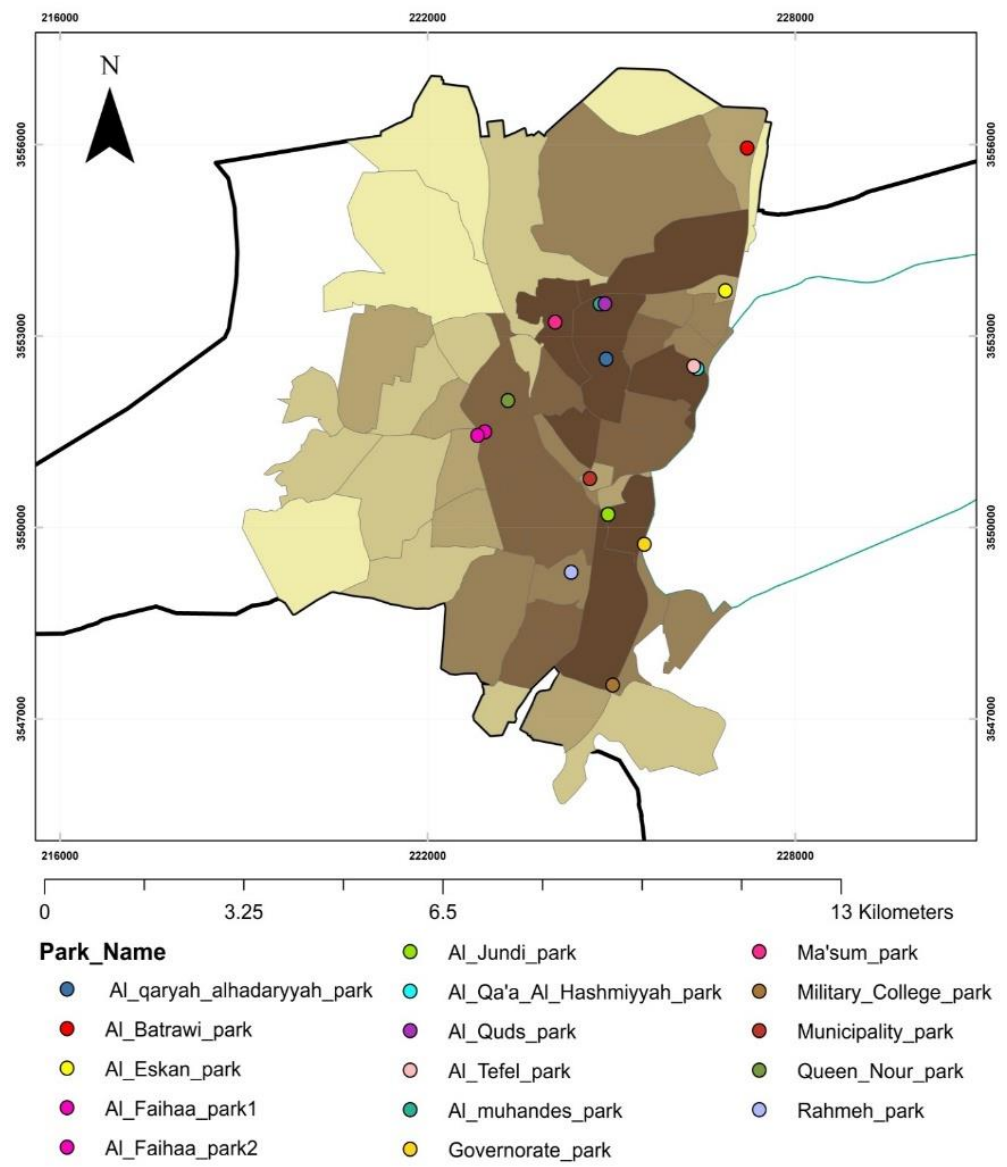

Figure 13. Distribution of parks in Zarqa (Source: The author 2018)

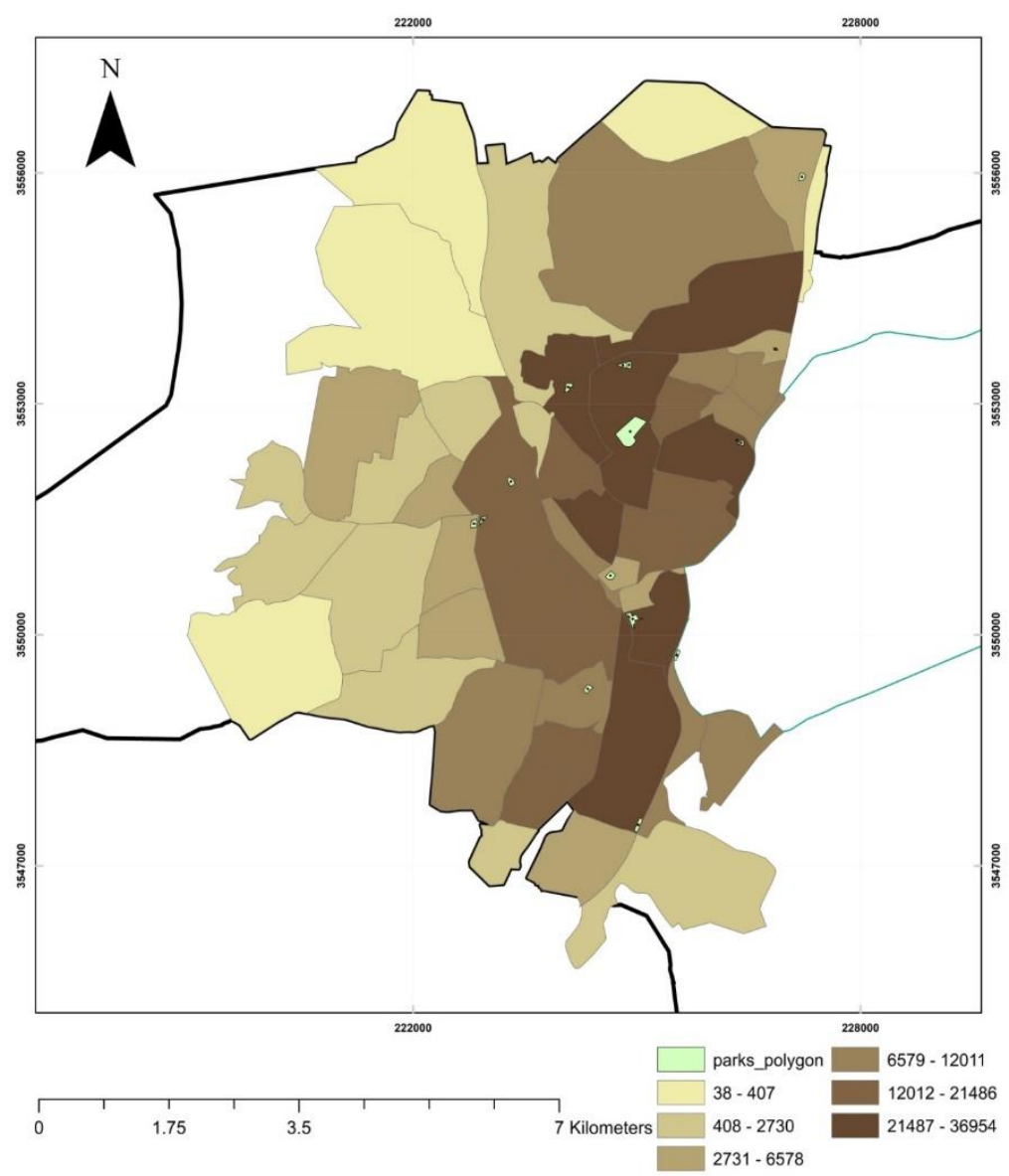

Figure 14. Shapes of parks and population densities in neighborhoods of Zarqa (Source: The author 2018) 


\subsubsection{Service areas according to the radius method}

Figure 15 displays the service areas in the 16 neighborhood parks in Zarqa City according to the radius analysis method. Mapping unveils that the access is limited to some immediate neighborhoods of each facility, leaving large areas throughout the city without access. Buffer zone analysis brings to notice that the service areas of the parks cover only $6.42 \mathrm{~km}^{2}$ of the overall $62 \mathrm{~km}^{2}$ area of Zarqa City. As such, these parks cover less than $10 \%$ of the city area within a service area domain of $400 \mathrm{~m}$.

5.2.4 Service areas according to the network analysis method The road network dataset was digitized manually and the road network (Figure 16) was drawn by using the network analysis extension in ArcGIS.

The service areas can be used to calculate the population or land area or any variable of interest in the neighborhood of any park because the buffer method includes the areas which are actually inaccessible due to the unavailability of pedestrian networks. As far as pedestrian accessibility is concerned, direct routes are preferred owing to that accessing the parks through non-linear routes takes more time than through linear routes. According to the network analysis, the service areas of the parks covered only around $2.25 \mathrm{~km}^{2}$ of the $62 \mathrm{~km}^{2}$ of area of the city of Zarqa. These 16 parks cover fewer than $3.6 \%$ of the city area (Figure 17).

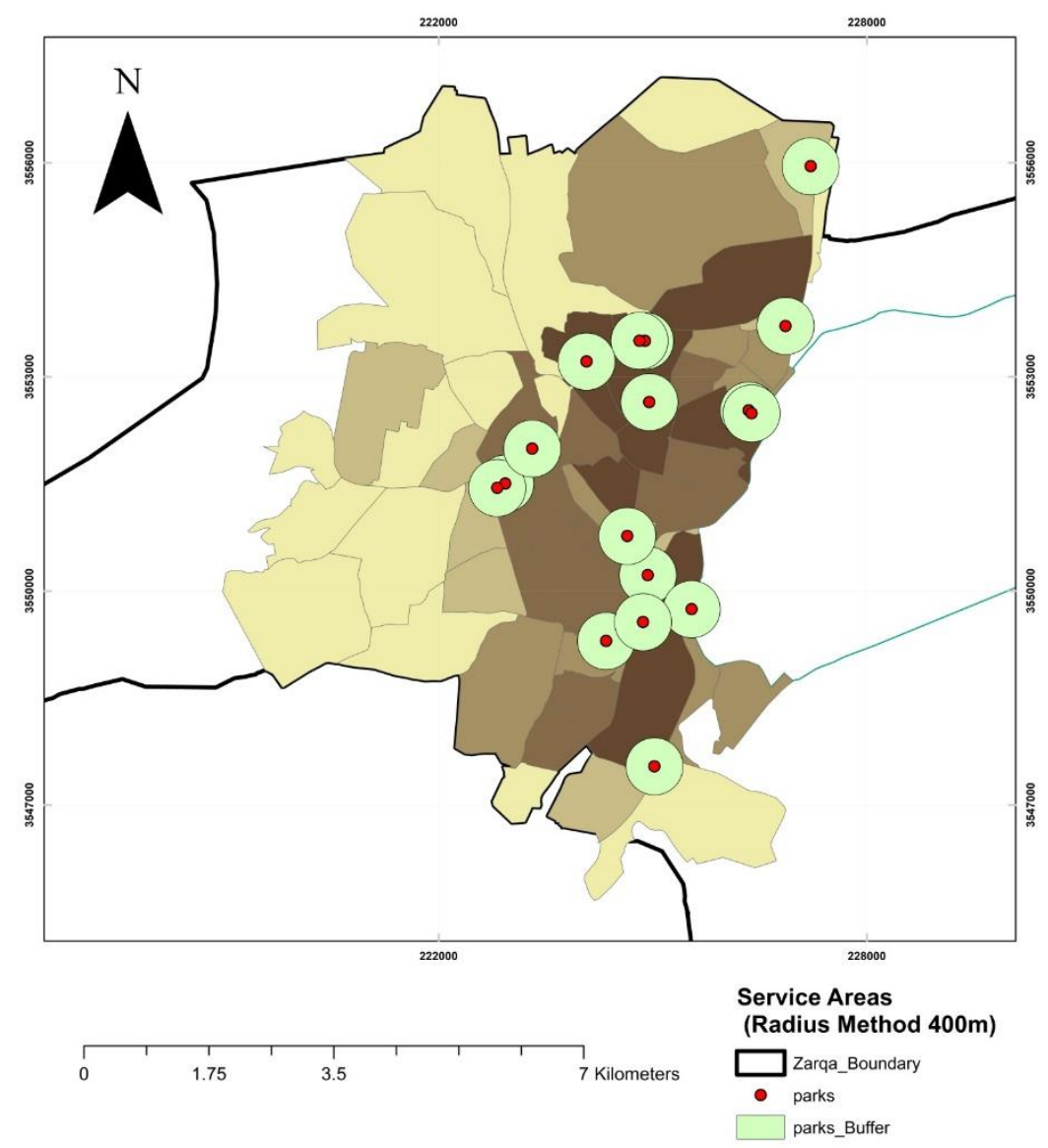

Figure15. The service areas in Zarqa City identified by the radius analysis method (Source: The author 2018)

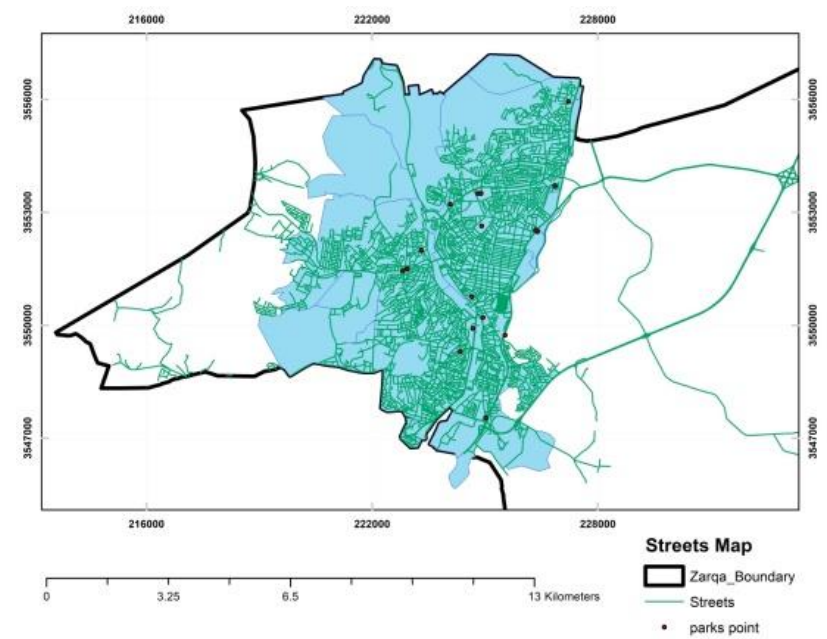

Figure 16. Map of streets in Zarqa City (Source: The author 2018)

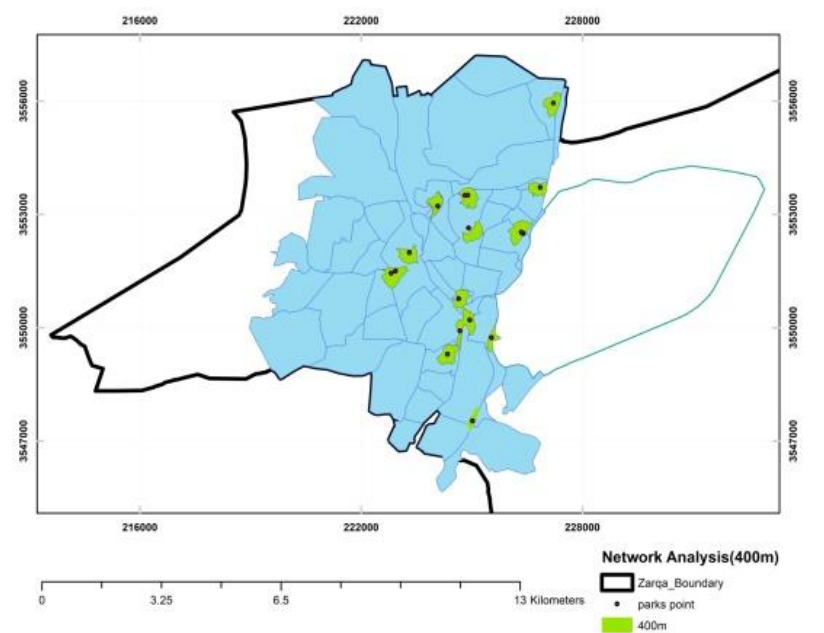

Figure 17. Network analysis of parks in Zarqa City (Source: The author 2018) 


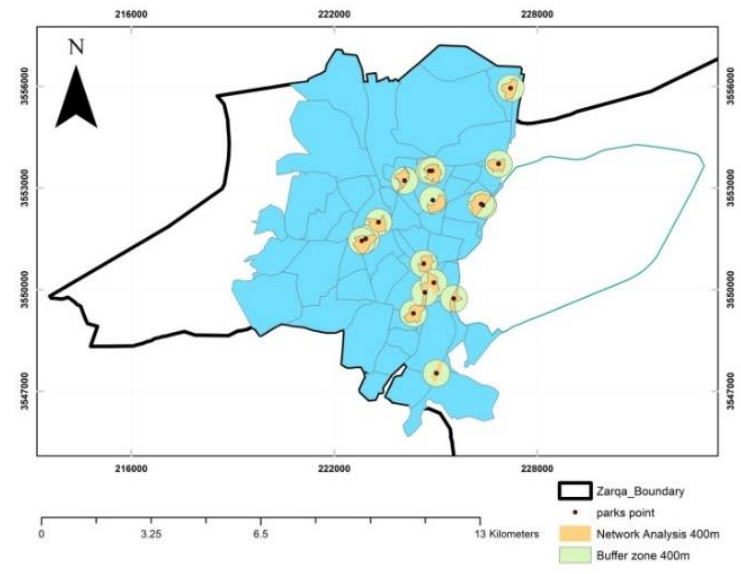

Figure 18. Service areas of Zarqa parks according to the radius and network analysis methods (Source: The author 2019)

The network analysis and radius analysis show that Zarqa City is only partially served by the parks and associated service areas (Figures 15-17). Most of the population in the west of the city is completely non-served. This means that people living in this particular zone have no park facilities to go to. In other respects, the maps and Figures (15-17) show differences between the two approaches to measurement of the distance as illustrated in Figure 18

As a result of population growth, the public open spaces in Zarqa City are not sufficient to meet people's needs. The results indicate that there is severe shortage of public open spaces in this city, which contains 16 parks that do not serve all the city population. These spaces cover only $6.5 \mathrm{~km}^{2}$ according to the radius analysis method and $2.5 \mathrm{~km}^{2}$ according to the network analysis method (Table 5) based on a service range of $400 \mathrm{~m}$.

On account of this, the population of Zarqa is not satisfied with the public open spaces available in the city, which are actually confined to parks. Accordingly, the phenomenon of informal spaces that are beginning to appear in the city is very much related to this shortage of public open spaces in the city. In the second questionnaire, the success of formal and informal spaces was tested using the chosen model indicators.

\subsection{The second questionnaire survey}

This section introduces the results derived from the questionnaire surveys that assist in developing of a spatial model for successful public open spaces. All indicators identified by the test model, namely, Charkhchian et al.'s [40] model, were tested in formal and informal spaces.

Table 5. Comparison between the results of the radius method and the network analysis method for Zarqa City (drawn up by the author 2019)

\begin{tabular}{cccc}
\hline & Serviced area & $\begin{array}{c}\text { The ratio of area of public open } \\
\text { spaces to area of the entire city }\end{array}$ & $\begin{array}{c}\text { The percentage of population } \\
\text { in the service area }\end{array}$ \\
\hline $\begin{array}{c}\text { Service areas according to the } \\
\text { radius method }\end{array}$ & $6.416736 \mathrm{~km}^{2}$ & $10 \%$ & $34.7 \%$ \\
$\begin{array}{c}\text { Service areas according to the } \\
\text { network analysis method }\end{array}$ & $2.249949 \mathrm{~km}^{2}$ & $3.6 \%$ & $12.17 \%$ \\
\hline
\end{tabular}

Table 6. Testing the success of indicators in formal and informal spaces (Source: Charkhchian and Daneshpour 2009). Modified by the researcher

\begin{tabular}{|c|c|c|c|c|}
\hline Dimension & Indicators & Measure(s) & Formal public space & Informal space \\
\hline \multirow[t]{5}{*}{ Physical } & Comfort and security & Security and protection from crime & success & success \\
\hline & Accessibility & A variety of transportation options & fail & success \\
\hline & Natural elements & Green spaces and water & fail & fail \\
\hline & Aesthetic values & Complexity, order, and enclosure & fail & fail \\
\hline & Amenities and facilities & Service, lighting, and waste receptacles & fail & success \\
\hline \multirow[t]{3}{*}{ Social } & Privacy and territory & $\begin{array}{l}\text { Is this a place which you will choose to meet your } \\
\text { friends in? }\end{array}$ & fail & success \\
\hline & Social events & $\begin{array}{l}\text { Are others meeting friends here or running into } \\
\text { them? }\end{array}$ & fail & fail \\
\hline & $\begin{array}{l}\text { Focal point gathering } \\
\text { spaces }\end{array}$ & $\begin{array}{l}\text { Are people in groups? } \\
\text { Are they talking with one another? } \\
\text { Do people bring their friends and relatives to see the } \\
\text { place or point to one of its features with pride? } \\
\text { Are people smiling? }\end{array}$ & success & success \\
\hline \multirow[t]{6}{*}{ Activity } & Activity in all parts & Which parts of the space are used and which are not? & success & success \\
\hline & Permanent use of place & Do people use the place regularly and by choice? & success & fail \\
\hline & Activity satisfaction & Are they satisfied? & fail & success \\
\hline & Different activities & $\begin{array}{l}\text { How many different types of activities are } \\
\text { organized? }\end{array}$ & success & success \\
\hline & Activity in different time & When are they present in the place? & success & success \\
\hline & Personal and group & Do they use the space as singles or as groups? & success & success \\
\hline \multirow[t]{4}{*}{ Meaning } & Cost of place & Cost of the place & fail & success \\
\hline & Time & $\begin{array}{l}\text { Time was evaluated with users' regular presence in } \\
\text { the place and length of their familiarity with it }\end{array}$ & fail & success \\
\hline & $\begin{array}{l}\text { Memories and place } \\
\text { history }\end{array}$ & If they remember any special memory from the place & fail & fail \\
\hline & Sign & Is there any memorable sign in? & fail & success \\
\hline
\end{tabular}


Respondents' feedback shows that the formal public open spaces failed in most indicators while succeeded in 7 of 18 considered indicators. On the other hand, the informal spaces have a higher degree of success where they succeeded in 13 of 18 indicators (See Table 6).

Special attention was paid by this study to identification of the shortages and challenges in the formal and informal public open spaces in Zarqa from the viewpoints of their visitors. Seventy-five respondents highlighted poor amenities and facilities in officially-organized spaces such as inadequate seats and lack of buffets and places for reading. In addition, fifty-four respondents indicated that the presence of natural elements was poor and 48 respondents complained about poor management of the officially-organized spaces. Furthermore, forty-three respondents pinpointed poor cleanliness in such spaces and 24 respondents highlighted that the lack of play facilities is a key challenge when using these spaces. Other prevalent challenges identified include poor lighting, lack of toilets, inadequacy of the space to use, lack of privacy, low, organization of activities, and inadequacy of the car parking lots (See Figure 19). As a consequence of the problems prevailing in the formal public open spaces, people tend to create new spaces that can meet their needs. In this regard, this study examined the informal public open spaces and highlighted their features to improve the future formal public open spaces (Figure 20).

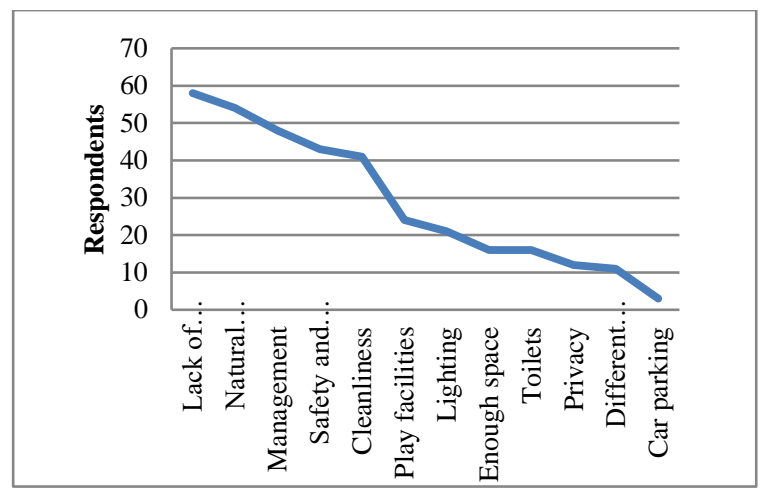

Figure 19. Shortage and challenges in the formal public open spaces in Zarqa (Source: The author 2019)

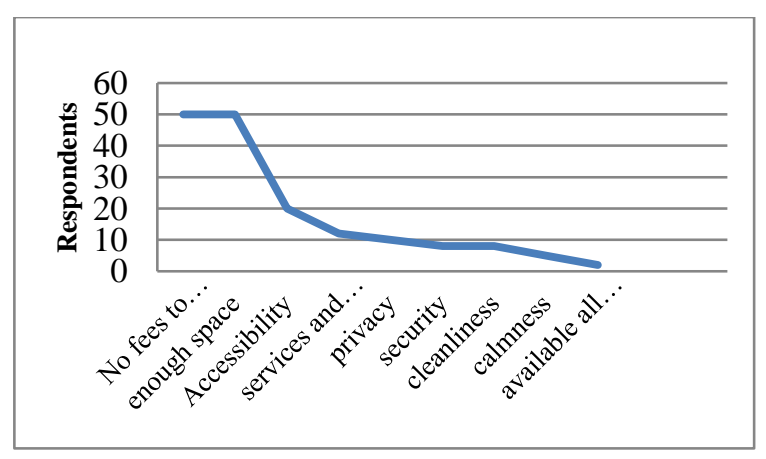

Figure 20. The characteristic features of the informal public open spaces in Zarqa (Source: The author 2019)

At the end of the survey, the respondents provided a number of solutions and suggestions to improve these spaces and design new ones that meet their preferences. During the field study, the users of the public open spaces in Zarqa were asked about their viewpoints on how the current conditions of these spaces can be improved. As Figure 21 illustrates, the individuals responded to the question related to users' suggestions for improving the conditions of formal spaces. Also the users of these spaces see that the first and topmost priority is enhancing the amenities and facilities in these spaces.

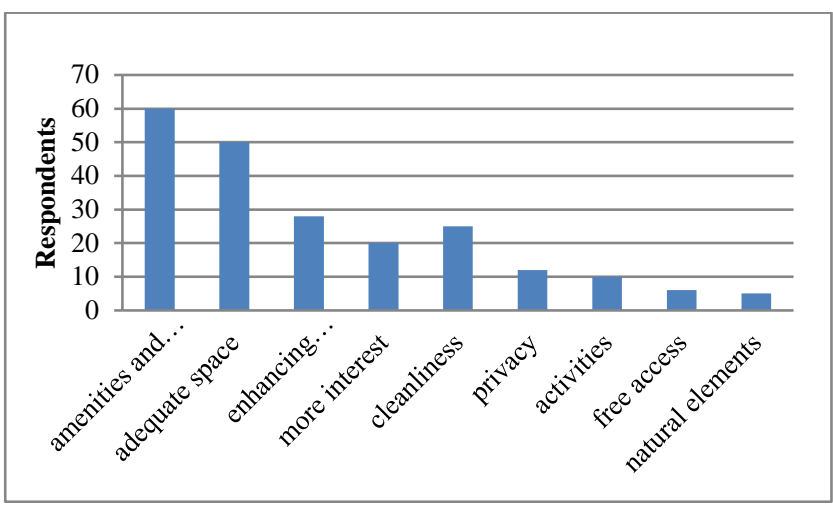

Figure 21. Suggestions to improve the officially-organized public open spaces in Zarqa (Source: The author 2019)

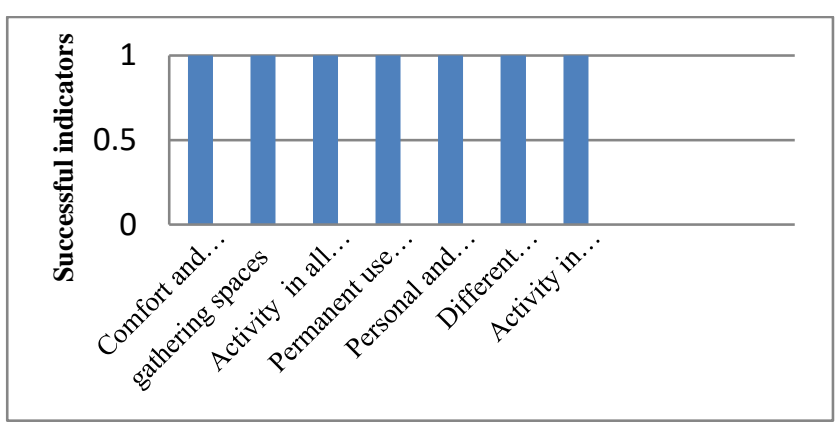

Figure 22. The successful indicators in formal spaces (1 mean success (Source: The author 2019)

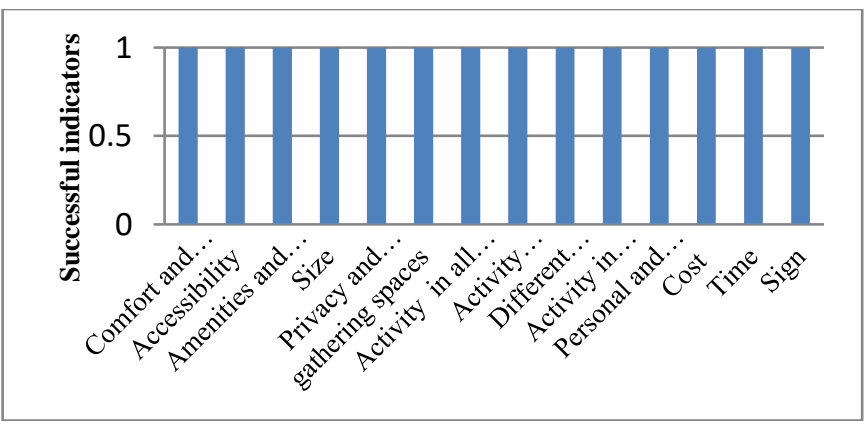

Figure 23. The successful indicators in informal spaces (1 mean success) (Source: The author 2019).

Figure (22) indicates a limited success of formal public open spaces, while the informal spaces succeeded and outpaced the formal public open spaces (Figure 23). These informal spaces attracted people because of their many advantages which encircle enough and open spaces, freedom of movement and activities, free access, privacy, and accessibility. There are various suitable indicators which help in determining how much successful the public open space is. These indicators are categorized into four dimensions: physical, social, activity, and meaning dimensions. The study provides a set of recommendations that aim to improve the design of formal public open spaces using successful informal spaces as an example. These include improvement and upgrading of the different activities, increasing the size of the spaces, and cancelling the entrance fees, comfort and security, and 
accessibility (Figure 23). Doing so will encourage multiple uses of the formal spaces and contribute to their success. Moreover, it recommends the official authorities to pay more attention to these public open spaces, especially in terms of cleanliness, privacy, and organization of varied activities.

\section{CONCLUSIONS AND RECOMMENDATIONS}

The study indicates that there are inadequate public open spaces in Zarqa City. Moreover, the existing public open spaces are quite poor and insecure and they do not contain sufficient facilities. In addition, the way of how the public open spaces are designed in Zarqa is boring. These spaces have many problems and face varying obstacles, resulting in their abandonment and loss. Furthermore, it founds that the formal spaces are unsafe, uncomfortable, and inflexible. Also, these spaces do not support varied activities and do not have enough space as well as these need entrance fees. These limitations contribute to the limited success of the public open spaces. Most of the officially-organized spaces do not have good amenities such as night lighting, toilets, seats, parking areas, and natural elements. The limited cleanliness is a serious problem and usually very few activities are organized in the spaces. Further, these spaces do not set a balance between privacy and variations among users. On account of this, these spaces do not accommodate different uses to meet users' needs. As a consequence of the problems prevailing in the formal public open spaces, people tend to create new informal spaces, which can meet their needs. It is worth mentioning that the informal spaces have become a focal point for the preferences and desires of the people. Therefore, this study recommends paying further attention to the informal spaces and to provision of important facilities.

Accordingly, this study concludes with a spatial model consists of multi-recommendation contributing the success of public open spaces in Zarqa City. This model gives an opportunity to bridge gaps and guide the government, municipal authorities, planners, engineers and decisionmakers responsible for designing public open spaces to enhance the future community-friendly spaces in cities suffering unplanned urban and population growth. In this context, the study identified (1) the shortage and challenges in the formal public open spaces in Zarqa; (2) A set of successful indicators in informal spaces and formal spaces; (3) A wide range of characteristic features of the informal public open spaces in Zarqa.; and (4) The suggestions to improve the officially-organized public open spaces in Zarqa.

Therefore, the study recommended a set of recommendations are represented in; (1) Enhancing and rehabilitating the current public open spaces in Zarqa to be more suitable and usable spaces;(2) Transformation of spaces and/or creation of new official spaces; (3) Engaging the community at the planning and design stages is essential for success of the public open spaces as this allows for knowing their needs and what exactly makes these spaces attractive for them; and (4) meeting varying human needs that encompass facilities and amenities, cleanliness, free entrance, comfort, privacy, security, and accessibility as basic needs, and aesthetic features and natural elements, as superior needs in these spaces.

Additionally, this study explored new indicator for the physical dimension, which is the size of the public open space. The people need a wide-open space to meet their needs.
Review of the literature brings to light that many studies affirm that the size of the park or public open space is an essential factor that affects its use. Giles-Cort, et al. [90] confirmed that after distance to public open spaces is taken into account, the size of the space is a highly-important factor in encouraging its use. In line with this, Holman et al. [91] stressed that park size affects its use in addition to the aesthetic features and the presence of amenities. In contrast, Janet and Rachel [92] found that the size of the public open space did not directly affect its use and the users' needs, contrary to the design and activities.

For general applicability, the spatial model proposed herein can be applied to other Jordanian cities and cities in other countries that are similar to Zarqa City in terms of urban development and population density. It can also be developed further in order to inform the similar works that are being undertaken in developing countries cities in terms of urban development and population growth.

\section{REFERENCES}

[1] Hajmirsadeghi, R.S. Shamsuddin, S., Lamit, H., Foroughi, A. (2014). Design's factors influencing social interaction in public squares. European Online Journal of Natural and Social Sciences, 2(4): 556-564. https://doi.org/10.13140/2.1.1988.7040

[2] Esbah, H., Deniz, B. (2007). Effects of land use development on urban open spaces. Journal of Applied Sciences, 7(8): 1138-1144.

[3] Mutuga, F. (2009). The effect of urbanization on protected areas. The Impact of Urban Growth on a Wildlife Protected Area: A Case Study of Nairobi National Park.

[4] Carmona, M. (2010a). Contemporary public space: Critique and classification, part one: Critique. Journal of Urban Design, 15(1): 123-148. https://doi.org/10.1080/13574800903435651

[5] Pasaogullari, N., Doratli, N. (2004). Measuring accessibility and utilization of public spaces in Famagusta. Cities, 21(3): 225-232. https://doi.org/10.1016/j.cities.2004.03.003

[6] Greater Zarqa Municipality (2016). Phase 1 of Planning for Local Economic Development, Municipal Strengthening Action Plan and Investment Opportunities, 2016.

[7] Greater Zarqa Municipality (2017). Studies and Design Department in Zarqa municipality, Report on the Parks and public open spaces in Zarqa city, 2017.

[8] Aljafari, M. (2014). Emerging public spaces in the city of Amman, Jordan: An analysis of everyday life practices. Unpublished Doctoral Dissertation, Dortmund University, https://doi.org/10.13140/RG.2.1.3827.4805

[9] Mattson, K. (1999). Reclaiming and remaking public space: Toward an architecture for American democracy. National Civic Review, 88(2): 133-144. https://doi.org/10.1002/ncr.88206

[10] Giddings, B., Charlton, J., Horne, M. (2011). Public squares in European city centres. Urban Design International, $\quad 16(3)$ : 202-212. https://doi.org/10.1057/udi.2011.6

[11] Truong, V.C. (2008). Sydney city's public open spaces. Unpublished master's thesis, University of New South Wales. 
[12] Lynch, K. (1981). A Theory of Good City Form, First Edit, The MIT Press. https://mitpress.mit.edu/books/theory-good-city-form.

[13] Eckbo, G. (1969). The Landscape We See, First edit, McGraw-Hill.

https://www.amazon.com/gp/product/0070188823/ref=x _gr_w_bb_sout?ie=UTF8\&tag=x_gr_w_bb_sout-

$20 \&$ linkCode $=$ as $2 \&$ camp $=1789 \&$ creative $=9325 \&$ creati veASIN=0070188823\&SubscriptionId=1MGPYB6YW 3HWK55XCGG2.

[14] Carmona, M., Heath, T., Tiesdell, S., Oc, T. (2010). Public Places - Urban Spaces- The Dimensions of Urban Design. 2nd Editio, Architectural Press. https://www.amazon.com/Public-Places-Urban-SpacesSecond/dp/1856178277.

[15] Dines, N., Cattell, V., Gesler, W., Curtis, S. (2006). Public spaces, social relations and well-being in East London: Joseph Rowntree Foundation. http://www.amazon.com/Public-spaces-social-relationswell-being/dp/1861349238.

[16] Oldenburg, R. (1999). Acclaim for Ray Oldenburg and The Great Good Place, 3rd ed., Marlowe \& Company. https://www.amazon.com/Great-Good-PlaceBookstores-Community/dp/1569246815.

[17] Weintraub, J. (1995). Varieties and vicissitudes of public space. Metropolis: Center and Symbol of Our Times, 280-319.

[18] Carmona, M. (2010b). Contemporary public space, part two: Classification. Journal of Urban Design, 15(2): 157173. https://doi.org/10.1080/13574801003638111

[19] Cantada, I. (2015). Public Spaces as Catalyst for Slum Upgrading.

https://blogs.worldbank.org/endpovertyinsouthasia/publ ic-spaces-catalyst-slum-upgrading.

[20] Abu-Ghazalah, S. (2004). The neighborhood concept in the Middle Eastern industrial cities: A definition and appraisal. Alexandria Engineering Journal, 43(1): 91-102.

[21] Bridge, H. (2015). Report of Informal Places For Active Recreation and Children's Play in Kampala Slums, Uganda.

https://healthbridge.ca/images/uploads/library/informalopen-spaces-report_final.pdf.

[22] Das, D. (2008). Urban quality of life: A case study of Guwahati. Social Indicators Research, 88(2): 297-310. https://doi.org/10.1007/s11205-007-9191-6

[23] Lambiri, D., Biagi, B., Royuela, V. (2007). Quality of life in the economic and urban economic literature. Social Indicators Research, 84(1): 1-25. https://doi.org/10.1007/s11205-006-9071-5

[24] Oldenburg, R., Brissett, D. (1982). The third place. Qualitative Sociology, 5(4): 265-284. https://doi.org/10.1007/BF00986754

[25] Carmona, M. (2019). Principles for public space design, planning to do better. Urban Design International, 24(1): 47-59. https://doi.org/10.1057/s41289-018-0070-3

[26] Orum, A.M., Neal, Z.P. (2009). Common Ground: Readings and Reflections on Public Space. Routledge. https://doi.org/10.1016/j.cub.2005.03.002

[27] Makworo, M., Mireri, C. (2011). Public open spaces in Nairobi City, Kenya, under threat. Journal of Environmental Planning and Management, 54(8): $1107-$ 1123. https://doi.org/10.1080/09640568.2010.549631

[28] Nicholls, S. (2001). Measuring the accessibility and equity of public parks: A case study using GIS.
Managing Leisure, 6(4): 201-219. https://doi.org/10.1080/13606710110084651

[29] Al Manasra, M., Al Manasra, A. (2016). The effect of the planning laws on the formation of the residential neighborhoods between theory and practice. In: 5th Jordan Int. Archit. Conf., 2016.

[30] Nasution, A.D., Zahrah, W. (2014). Community perception on public open space and quality of life in Medan, Indonesia. Procedia-Social and Behavioral Sciences, 153: 585-594. https://doi.org/10.1016/j.sbspro.2014.10.091

[31] Officha, M.C., Onwuemesi, F.E., Akanwa, A.O. (2012). Problems and prospect of open spaces management in Nigeria: The way forward. World Journal of Environmental Biosciences, 2(1): 7-12.

[32] Askari, A.H., Soltani, S. (2019). Determinants of a successful public open space: The case of Dataran Merdeka in the city centre of Kuala Lumpur, Malaysia. Landscape Research, 44(2): 162-173. https://doi.org/10.1080/01426397.2018.1427221

[33] Chen, Y., Liu, T., Xie, X., Marušić, B.G. (2016). What attracts people to visit community open spaces? A case study of the Overseas Chinese Town community in Shenzhen, China. International Journal of Environmental Research and Public Health, 13(7): 644. https://doi.org/10.3390/ijerph13070644

[34] Bakar, N.A., Malek, N.A., Mansor, M. (2016). Access to parks and recreational opportunities in urban low-income neighbourhood. Procedia-Social and Behavioral Sciences, 234: 299-308. https://doi.org/10.1016/j.sbspro.2016.10.246

[35] Kaczynski, A.T., Potwarka, L.R., Smale, B.J., Havitz, M.E. (2009). Association of parkland proximity with neighborhood and park-based physical activity: Variations by gender and age. Leisure Sciences, 31(2): 174-191. https://doi.org/10.1080/01490400802686045

[36] Sherer, P.M. (2003). The benefits of parks: Why America needs more city parks and open space. Trust for Public Land, (2006): 1-37.

[37] Carr, S., Stephen, C., Francis, M., Rivlin, L.G., Stone, A.M. (1992). Public space. Cambridge University Press, 1993. https://www.amazon.com/Public-SpaceEnvironment-Behavior-Stephen/dp/0521351480.

[38] Krueger, M.W. (1977). Responsive environments. In Proceedings of the June 13-16, 1977, National Computer Conference, pp. 423-433. https://doi.org/10.4135/9781412950657.n201

[39] Carmona, M., Heath, T., Oc, T., Tiesdell, S. (2003). Urban spaces-public places: The dimensions of urban design. Architectural Press.

[40] Charkhchian, M., Daneshpour, S.A. (2009). Interactions among different dimensions of a responsive public space: Case study in Iran. In Review of Urban \& Regional Development Studies: Journal of the Applied Regional Science Conference, 21(1): 14-36. https://doi.org/10.1111/j.1467-940X.2009.00157.x.

[41] Ulrich, R.S. (1984). View through a window may influence recovery from surgery. Science, 224(4647): 420-421. https://doi.org/10.1126/science.6143402

[42] Baba, Y., Austin, D.M. (1989). Neighborhood environmental satisfaction, victimization, and social participation as determinants of perceived neighborhood safety. Environment and Behavior, 21(6): 763-780. https://doi.org/10.1177/0013916589216006 
[43] Woolley, H. (2004). Urban Open Spaces, Taylor \& Francis, 2004. https://doi.org/10.1017/CBO9781107415324.004

[44] Rishbeth, C. (2001). Ethnic minority groups and the design of public open space: An inclusive landscape? Landscape Research, 26(4): 351-366. https://doi.org/10.1080/01426390120090148

[45] Gifford, R. (2007). Environmental psychology: Principles and practice. 372. Colville, WA: Optimal books. https://www.amazon.com/EnvironmentalPsychology-Principles-Practice-gifford/dp/0968854311.

[46] Gehl, J. (2011). Life Between Buildings: Using Public Space. Sixth Edit, Island Press. https://doi.org/10.3368/lj.8.1.54

[47] Alshawabkeh, R., Alhaddad, M. (2018). High density mixed use as an effective scheme in applying sustainable urban design principles in Amman, Jordan. Int. J. Humanit. Social Sci, 7(10): 57-78.

[48] Whyte, W.H. (1980). The Social Life of Small Urban Spaces. Project for Public Spaces. New York. https://doi.org/10.4324/9780203873960

[49] Loukaitou-Sideris, A., Banerjee, T. (1998). Urban design downtown: Poetics and politics of form. Univ of California Press. https://www.amazon.com/UrbanDesign-Downtown-Poetics-Politics/dp/0520209303.

[50] Green, R. (1999). Meaning and form in community perception of town character. Journal of Environmental Psychology, 19(4): 311-329. http://linkinghub.elsevier.com/retrieve/pii/S0272494499 901433.

[51] Cohen, Y.S., Shinar, A. (1985). Neighborhoods and friendship networks: A study of three residential neighborhoods in Jerusalem 215. Univ of Chicago Committee https://www.amazon.com/Neighborhoods-FriendshipNetworks-Residential-University/dp/0890651205.

[52] Korpela, K., Hartig, T. (1996). Restorative qualities of favorite places. Journal of Environmental Psychology, 16(3): 221-233. https://doi.org/10.1006/jevp.1996.0018

[53] Oswald, F., Wahl, H.W. (2001). Housing in old age: Conceptual remarks and empirical data on place attachment. Bulletin on People-Environment Studies, 19: 8-12.

https://www.researchgate.net/publication/313485838_H ousing_in_old_age_Conceptual_remarks_and_empirical _data_on_place_attachment.

[54] Altman, I. (1993). Dialectics, physical environments, and personal relationships. Communications Monographs, 60(1): https://doi.org/10.1080/03637759309376291

[55] Stauskis, G., Eckardt, F. (2011). Empowering public spaces as catalysers of social interactions in Urban communities. Town Planning and Architecture, 35(2): 117-128. https://doi.org/10.3846/tpa.2011.14

[56] Al Shawabkeh, R.K. (2018). New urban regeneration for the city of Amman using sustainable urban design principles: Al-Abdali Area as a case study. International Journal of Applied Engineering Research, 13(19): 14345-14358.

[57] Németh, J., Hollander, J. (2010). Security zones and New York City's shrinking public space. International Journal of Urban and Regional Research, 34(1): 20-34. https://doi.org/10.1111/j.1468-2427.2009.00899.x

[58] Billingham, J. (2002). The Good Place Guide: Urban
Design in Britain and Ireland. Sterling Publishing Company, Inc. https://www.amazon.in/GOOD-PLACEGUIDE-John-Billingham/dp/0713487860.

[59] Paravicini, U. (2003). Public spaces as a contribution to egalitarian cities. In City and Gender. VS Verlag für Sozialwissenschaften, Wiesbaden, 57-80. https://link.springer.com/chapter/10.1007/978-3-32297563-8_4\#citeas.

[60] Telford, T. (2001). The Value of Urban Design. A research project commissioned by CABE and DETR to examine the value added by good urban design. https://www.designcouncil.org.uk/sites/default/files/ass et/document/the-value-of-urban-design_0.pdf.

[61] Project for Public Spaces (PPS), U.S.A. What Makes A Successful Place? http://www.pps.org/articles/grplacefeat/. downloaded in 2017.

[62] Unal, M., Uslu, C., Cilek, A. (2016). GIS-based accessibility analysis for neighbourhood parks: The case of Cukurova district. Journal of Digital Landscape Architecture, 1: 46-56. https://doi.org/10.14627/537612006

[63] Sakip, S.R.M., Akhir, N.M., Omar, S.S. (2015). Determinant factors of successful public parks in Malaysia. Procedia-Social and Behavioral Sciences, 170: 422-432. https://doi.org/10.1016/j.sbspro.2015.01.003

[64] Salih, S.A., Ismail, S. (2017). Criteria for public open space enhancement to achieve social interaction: A review paper. In IOP Conference Series: Materials Science and Engineering, 291(1): 012001. https://doi.org/10.1088/1757-899X/291/1/012001

[65] Mangunsong, N.I. (2018). Factors affecting quality of social interaction park in Jakarta. In IOP Conference Series: Earth and Environmental Science, 106(1): 012055 .

https://doi.org/10.1088/1755$1315 / 106 / 1 / 012055$

[66] Suzanne L., Crowhurst, H. (1987). Livable Cities: People and Places: Social and Design Principles for the Future of the City, Gondolier Pr Imcl Council. https://www.amazon.com/Livable-Cities-People-PlacesPrinciples/dp/0935824049.

[67] Gehl, J., Soholt, H.L. (2002). Public spaces and public life: City of Adelaide, Planning SA, Adelaide. http://userplatform.lametro.fr/wp-

content/uploads/2013/07/public_spaces_and_public_life _report.pdf.

[68] McColl, R.W. (2014). Encyclopedia of World Geography. 1. Infobase Publishing.

[69] Al-Shawabkeh, R., Alhaddad, M.I., Gandah, F. (2016). Post-occupancy evaluation for ceremonial and public buildings: A case study of Amman City Hall, Jordan. Journal of Civil Engineering and Architecture, 10: 13731383. https://doi.org/10.17265/1934-7359/2016.12.008.

[70] Rjoub, A., Al-Shawabkeh, R. (2018). Urban and architectural impacts of hejaz railway in Mafraq-Jordan. International Journal of Humanities and Social Science, 8(1): 121-131.

[71] Alzouby, A.M., Al-Shawabkeh, R.K., Dweiri, A.M.M. (2019). Integrated infrastructure: A study of rehabilitation of Al-Akaider landfill. Alexandria Engineering Journal, 58(1): 261-271. https://doi.org/10.1016/j.aej.2019.02.003

[72] Ministry of Municipals Affairs (MMA) (2018). Background: Hashemite Kingdom of Jordan. 
http://www.mma.gov.jo.

[73] Jordan Department of Statistics (DOS) (2018). Hashemite Kingdom of Jordan Census: Population Density 2018. Report prepared by the Department of Statistics. http://dosweb.dos.gov.jo/.

[74] Abu-Ghazalah, S. (1997). An outlook on jordan urban public open space: The case- study of Zarqa City, AlMansura University. Faculty of Engineering Magazine, 22(1): 1-18

[75] Al Shawabkeh, R.K., Alzouby, A.M., Rjoub, A., Alsmadi, M., AlKhamaiseh, M., Shboul, D., Smadi, A., Al-Bzour, A., Al-Omari, R. and Alobaidat, E. (2020). Evaluating the satisfaction rate for a ff ordable housing in non- gated residential area ( NGR ): The case of AlSharq housing project in Zarqa-Jordan. International Journal of Housing Markets and Analysis, Ahead-ofprint. https://doi.org/10.1108/IJHMA-10-2019-0105

[76] Ministry of Culture (2018). Historical Background: Hashemite Kingdom of Jordan. http://www.culture.gov.jo.

[77] Greater Amman Municipality (2008). The Amman plan metropolitan growth report, 2008. https://www.ammancity.gov.jo.

[78] Mean, M., Tims, C. (2005). People make places: Growing the public life of cities. Demos.

[79] Turel, H.S., Yigit, E.M., Altug, I. (2007). Evaluation of elderly people's requirements in public open spaces: A case study in Bornova District (Izmir, Turkey). Building and Environment, 42(5): 2035-2045. https://doi.org/10.1016/j.buildenv.2006.03.004

[80] O'Cathain, A., Murphy, E., Nicholl, J. (2007). Why, and how, mixed methods research is undertaken in health services research in England: A mixed methods study. BMC Health Services Research, 7(1): 85.

[81] Al Shawabkeh, R., Bagaeen, S., Al_Fugara, A., Hijazi, H. (2019). The role of land use change in developing city spatial models in Jordan: The case of the Irbid master plan (1970-2017). Alexandria Engineering Journal, 58(3): $861-875$ https://doi.org/10.1016/j.aej.2019.08.001

[82] Phillips, D.S., Pugh, E.M. (2005). How To Get a PhD. Open University Press; 5 edition
https://www.amazon.com/How-get-PhD-handbooksupervisors/dp/0335242022.

[83] Clarke, K.C. (1995). Analytical and Computer Cartography, 1. Englewood Cliffs, NJ: Prentice Hall.

[84] Al-Kodmany, K. (2000). GIS in the urban landscape: Reconfiguring neighbourhood planning and design processes. Landscape Research, 25(1): 5-28. https://doi.org/10.1080/014263900113145

[85] Balasubramani, K., Gomathi, M., Prasad, S. (2017). GISbased service area analysis for optimal planning strategies: A case study of fire service stations in madurai city, 11-18.

[86] The National Organization for Civilization Coordination (2010). Report of The standards and guidelines of urban coordination for open and green spaces in Egypt. http://www.urbanharmony.org/guide/mosthat\%20khdra a.pdf.

[87] De Vaus, D. (2002). Surveys In Social Research (Social Research Today). Routledge, 6th Edition, London. https://www.amazon.com/Surveys-Social-ResearchToday/dp/0415530180.

[88] Mitra, A. (1999). Research methods in park, recreation, and leisure services (No. 04; GV14. 5, M5.).

[89] Chiesura, A. (2004). The role of urban parks for the sustainable city. Landscape and Urban Planning, 68(1): 129-138. https://doi.org/10.1016/j.landurbplan.2003.08.003

[90] Giles-Corti, B., Broomhall, M.H., Knuiman, M., Collins, C., Douglas, K., Ng, K., Donovan, R.J. (2005). Increasing walking: How important is distance to, attractiveness, and size of public open space? American Journal of Preventive Medicine, 28(2): 169-176. https://doi.org/10.1016/j.amepre.2004.10.018

[91] Holman, C.D., Donovan, R.J., Corti, B. (1996). Factors influencing the use of physical activity facilities: Results from qualitative research. Health Promotion Journal of Australia: Official Journal of Australian Association of Health Promotion Professionals, 6(1): 16.

[92] Talbot, J.F., Kaplan, R. (1986). Judging the sizes of urban open areas: Is bigger always better? Landscape Journal, 5(2): 83-92. https://doi.org/10.3368/lj.5.2.83 